NASA/TM-2008-215005

AIAA-2007-5741

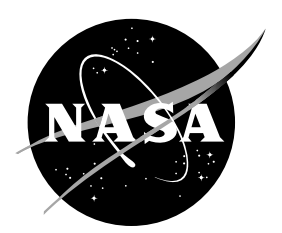

\title{
Characteristics of Elastomer Seals Exposed to Space Environments
}

\author{
Christopher C. Daniels
}

The University of Akron, Akron, Ohio

Henry C. de Groh III, Patrick H. Dunlap, Jr., Joshua R. Finkbeiner, and Bruce M. Steinetz Glenn Research Center, Cleveland, Ohio

Marta B. Bastrzyk

Illinois Institute of Technology, Chicago, Illinois

Jay J. Oswald

$J \& J$ Technical Solution, Inc., Middleburg Heights, Ohio

Bruce A. Banks, Joyce A. Dever, and Sharon K. Miller

Glenn Research Center, Cleveland, Ohio

Deborah L. Waters

ASRC Aerospace Corporation, Cleveland, Ohio 


\section{NASA STI Program . . . in Profile}

Since its founding, NASA has been dedicated to the advancement of aeronautics and space science. The NASA Scientific and Technical Information (STI) program plays a key part in helping NASA maintain this important role.

The NASA STI Program operates under the auspices of the Agency Chief Information Officer. It collects, organizes, provides for archiving, and disseminates NASA's STI. The NASA STI program provides access to the NASA Aeronautics and Space Database and its public interface, the NASA Technical Reports Server, thus providing one of the largest collections of aeronautical and space science STI in the world. Results are published in both non-NASA channels and by NASA in the NASA STI Report Series, which includes the following report types:

- TECHNICAL PUBLICATION. Reports of completed research or a major significant phase of research that present the results of NASA programs and include extensive data or theoretical analysis. Includes compilations of significant scientific and technical data and information deemed to be of continuing reference value. NASA counterpart of peer-reviewed formal professional papers but has less stringent limitations on manuscript length and extent of graphic presentations.

- TECHNICAL MEMORANDUM. Scientific and technical findings that are preliminary or of specialized interest, e.g., quick release reports, working papers, and bibliographies that contain minimal annotation. Does not contain extensive analysis.

- CONTRACTOR REPORT. Scientific and technical findings by NASA-sponsored contractors and grantees.
- CONFERENCE PUBLICATION. Collected papers from scientific and technical conferences, symposia, seminars, or other meetings sponsored or cosponsored by NASA.

- SPECIAL PUBLICATION. Scientific, technical, or historical information from NASA programs, projects, and missions, often concerned with subjects having substantial public interest.

- TECHNICAL TRANSLATION. Englishlanguage translations of foreign scientific and technical material pertinent to NASA's mission.

Specialized services also include creating custom thesauri, building customized databases, organizing and publishing research results.

For more information about the NASA STI program, see the following:

- Access the NASA STI program home page at http://www.sti.nasa.gov

- E-mail your question via the Internet to help@sti.nasa.gov

- Fax your question to the NASA STI Help Desk at 301-621-0134

- Telephone the NASA STI Help Desk at 301-621-0390

- Write to: NASA Center for AeroSpace Information (CASI) 7115 Standard Drive Hanover, MD 21076-1320 
NASA/TM-2008-215005

AIAA-2007-5741

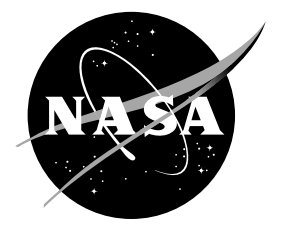

\section{Characteristics of Elastomer Seals Exposed to Space Environments}

Christopher C. Daniels

The University of Akron, Akron, Ohio

Henry C. de Groh III, Patrick H. Dunlap, Jr. , Joshua R. Finkbeiner, and Bruce M. Steinetz Glenn Research Center, Cleveland, Ohio

Marta B. Bastrzyk

Illinois Institute of Technology, Chicago, Illinois

Jay J. Oswald

$J \&$ J Technical Solution, Inc., Middleburg Heights, Ohio

Bruce A. Banks, Joyce A. Dever, and Sharon K. Miller

Glenn Research Center, Cleveland, Ohio

Deborah L. Waters

ASRC Aerospace Corporation, Cleveland, Ohio

Prepared for the

43rd Joint Propulsion Conference and Exhibit

cosponsored by the AIAA, ASME, SAE, and ASEE

Cincinnati, Ohio, July 8-11, 2007

National Aeronautics and

Space Administration

Glenn Research Center

Cleveland, Ohio 44135 


\section{Acknowledgments}

The authors wish to thank the TA Aerospace Division of Esterline Corporation for developing the ELA-SA-401 silicone elastomer compound for this application and Parker-Hannifin Corporation for supplying the S0383-70 and S0899-50 elastomer compounds. The authors wish to acknowledge the work provided by Akron Rubber Development Laboratories of Akron, Ohio.

Trade names and trademarks are used in this report for identification only. Their usage does not constitute an official endorsement, either expressed or implied, by the National Aeronautics and Space Administration.

Level of Review: This material has been technically reviewed by technical management.

Available from

NASA Center for Aerospace Information 7115 Standard Drive

Hanover, MD 21076-1320
National Technical Information Service 5285 Port Royal Road Springfield, VA 22161

Available electronically at http://gltrs.grc.nasa.gov 


\title{
Characteristics of Elastomer Seals Exposed to Space Environments
}

\author{
Christopher C. Daniels \\ The University of Akron \\ Akron, Ohio 44325-3901 \\ Henry C. de Groh III, Patrick H. Dunlap, Jr., Joshua R. Finkbeiner, and Bruce M. Steinetz \\ National Aeronautics and Space Administration \\ Glenn Research Center \\ Cleveland, Ohio 44135 \\ Marta B. Bastrzyk \\ Illinois Institute of Technology \\ Chicago, IL 60616 \\ Jay J. Oswald \\ J \& J Technical Solution, Inc. \\ Middleburg Heights, Ohio 44130 \\ Bruce A. Banks, Joyce A. Dever, and Sharon K. Miller \\ National Aeronautics and Space Administration \\ Glenn Research Center \\ Cleveland, Ohio 44135 \\ Deborah L. Waters \\ ASRC Aerospace Corporation \\ Cleveland, Ohio 44135
}

\begin{abstract}
A universal docking and berthing system is being developed by the National Aeronautics and Space Administration (NASA) to support all future space exploration missions to low-Earth orbit (LEO), to the Moon, and to Mars. The Low Impact Docking System (LIDS) is being designed to operate using a seal-on-seal configuration in numerous space environments, each having unique exposures to temperature, solar radiation, reactive elements, debris, and mission duration. As the LIDS seal is likely to be manufactured from an elastomeric material, performance evaluation of elastomers after exposure to atomic oxygen (AO) and ultraviolet radiation (UV) was conducted, of which the work presented herein was a part. Each of the three candidate silicone elastomer compounds investigated, including Esterline ELA-SA-401, and Parker Hannifin S0383-70 and S0899-50, was characterized as a low outgassing compound, per ASTM E595, having percent total mass loss (TML) less than $1.0 \%$ and collected volatile condensable materials (CVCM) less than $0.1 \%$. Each compound was compatible with the LIDS operating environment of -50 to $50{ }^{\circ} \mathrm{C}$. The seal characteristics presented include compression set, elastomer-to-elastomer adhesion, and o-ring leakage rate. The ELA-SA-401 compound had the lowest variation in compression set with temperature. The S0383-70 compound exhibited the lowest compression set after exposure to AO and UV. The adhesion for all of the compounds was significantly reduced after exposure to $\mathrm{AO}$ and was further decreased after exposure to AO and $\mathrm{UV}$. The leakage rates of o-ring specimens showed modest increases after exposure to AO. The leakage rates after exposure to $\mathrm{AO}$ and $\mathrm{UV}$ were increased by factors of up to 600 when compared to specimens in the as-received condition.
\end{abstract}

\section{Nomenclature}

AO atomic oxygen

APAS Androgynous Peripheral Assembly System

CBM Common Berthing Mechanism

CEV Crew Exploration Vehicle 


$\begin{array}{ll}\text { CVCM } & \text { collected volatile condensable materials } \\ \text { ESH } & \text { equivalent sun hours } \\ \text { ISS } & \text { International Space Station } \\ \text { LEO } & \text { low-Earth orbit } \\ \text { LIDS } & \text { Low Impact Docking System } \\ \text { LVDT } & \text { linear variable displacement transformer } \\ \text { NASA } & \text { National Aeronautics and Space Administration } \\ \text { NUV } & \text { near ultraviolet radiation } \\ \text { RTD } & \text { resistance temperature detector } \\ \text { TML } & \text { total mass loss } \\ \text { UV } & \text { ultraviolet radiation } \\ \text { VUV } & \text { vacuum ultraviolet radiation }\end{array}$

\section{Introduction}

The National Aeronautics and Space Administration (NASA) is developing the Low Impact Docking System (LIDS) ${ }^{1}$ for in-space assembly of structures and rendezvous of vehicles to enable mission profiles that will ensure the success of NASA's Vision for Space Exploration. The LIDS eliminates the need for high velocity docking, provides low velocity berthing assembly, and establishes a standard interface that is reconfigurable and supports a wide range of crewed and autonomous vehicle mating and assembly operations. The LIDS is a fully androgynous mating interface designed for a wide variety of space missions, reducing the quantity of unique mechanisms, mission analyses, and training by providing the ability to structurally connect with replicate LIDS. The objective of the LIDS development effort is to provide a universal linkage attached to every in-space structure and vehicle which will join to any other in-space structure.

The mating systems currently in use, including the Common Berthing Mechanism (CBM) used to connect elements of the International Space Station (ISS) and the Androgynous Peripheral Assembly System (APAS) used to dock the Space Shuttle to the ISS, can function either as a berthing or docking mechanism, but not both. Docking refers to the mating between two free-flying structures or vehicles which are generally crewed. The joining of two structures using a robotic arm, generally unmanned autonomous modules, is referred to as berthing. Though the APAS was originally designed to be androgynous, the interface seal attached to the ISS was subsequently removed. These mating systems, in their current configurations, are composed of two non-identical halves (a male and a female), which limits their functionality to mating with structures having the opposite gender interface.

The LIDS is a fully androgynous system, such that each system half is an identical replicate of any other. Any two vehicles or modules, each having a LIDS incorporated, can mate with the other without regard for gender. At the time of mating, one LIDS is selected as the active side; the other is selected as the passive side. This type of interface provides full system redundancy which improves fault tolerance. Should a mechanism failure occur in the active LIDS, the roles are reversed such that the active is designated passive and the failure circumvented.

The androgynous nature of the LIDS creates challenges for the sealing interface between the two pressurized modules. Since each system half is an exact replicate of its mating counterpart, the gas seals must interact with a identical seal instead of a more conventional flat surface. This unconventional interaction between the gas seals adds adhesion between two similar elastomer seals as an important design consideration in addition to seal compression set and leakage flow rate, amongst others. If the adhesion forces are too great, the seals will not allow the vehicles to separate from one another without excessive force. Additionally, the possibility of dislodging one of the two systems' seals is real. Even the partial removal of one of the seals would render the attachment interface useless and must be avoided.

The operating and non-operating environments of the LIDS also create challenges for the development of the LIDS main interface seal. The non-operating environment includes the space environments to which the seal is exposed when the LIDS is not mated to another LIDS. Overcoming the synergistic effects of atomic oxygen (AO), ultraviolet and particle radiation, and debris (micrometeoroids, orbital debris, and dust) is the most problematic. The operating environment includes the temperature range to which the seal is expected to be exposed when performing docking/undocking operations. The envelope into which the LIDS seal must be designed greatly affects the performance characteristics of the seal and must be considered when developing the system. The basis for the seal design, however, is the underlying performance of the elastomers within the operating and non-operating environments. 
At low altitudes, oxygen is a diatomic molecule $\left(\mathrm{O}_{2}\right)$, however, in the upper atmosphere of low-Earth orbit (LEO) photodissociation of the molecular bond between the two oxygen atoms occurs. Monatomic oxygen, or atomic oxygen, is created and is highly reactive. The exposure of unprotected materials to $\mathrm{AO}$ can greatly degrade performance depending upon their resistivity to oxidizing environments. The amount of AO to which the unshielded seals would be exposed will vary depending upon the mission altitude and solar activity during the mission. The average value for expected AO fluence for the years $2006-2016$ is $2.0 \times 10^{21}$ oxygen atoms $/ \mathrm{cm}^{2} /$ year $\left(1.3 \times 10^{22}\right.$ atoms $/ \mathrm{in}^{2} /$ year) based upon a nominal ISS orbital trajectory. ${ }^{2}$

For organic compounds, including silicone elastomers considered herein, the exposure to ultraviolet radiation (UV) can be a strong contributor to degradation. In orbits around the Earth and Moon, as well as on the lunar surface, incident UV scissors long molecule chains. The broken bonds recombine, thereby cross-linking intertwined molecular chains. The results are shorter molecular chains than the originals and a compound with modified properties, including increased stiffness. After excessive exposure to UV, organic materials embrittle and become unusable for seal applications.

Earth and lunar surface albedo cannot be discounted for long duration missions. Though little UV is reflected from the surface $\left(29 \%\right.$ from the Earth ${ }^{3}$ and $7.5 \%$ from the $\left.\mathrm{Moon}^{4}\right)$, the additive effect of long time exposures can be potentially significant. Therefore, the amount of UV to which the unshielded seal is expected to be exposed is highly dependant upon the mission and careful consideration must be given to the mission duration and profile. For example, a nose nadir at noon solar inertia orbit of the Moon for 210 days would expose the LIDS seal to a UV exposure of 126 equivalent Sun hours (ESH); the exposure for a nose nadir at midnight solar inertia orbit would be $3190 \mathrm{ESH}$.

The current LIDS design does not have accommodations for a thermal management system to control the temperature of the LIDS, its tunnel, or the seal. Therefore, the temperature can be actively adjusted only by managing the heat flux generated through solar heating. The operating temperature envelope of the LIDS is -50 to $50{ }^{\circ} \mathrm{C}\left(-58\right.$ to $\left.122^{\circ} \mathrm{F}\right)$.

Silicone elastomer compounds are typically used for seals for space flight applications where extreme heat is not a factor. Silicone elastomer compounds have a large range of operating temperatures and can function at cold temperatures better than other elastomer compound classes, due to their low embrittlement temperatures. However, only a limited number of silicone elastomers meet the low-outgas standards that NASA requires of all materials used in space. NASA specifies that all materials used for external spacecraft structures exhibit low-outgassing characteristics, as liberated products can condense onto solar cells, optical components, and thermal radiators, reducing their functionality. Materials exhibiting minimal volatility, total mass loss (TML) less than $1.0 \%$ and collected volatile condensable materials (CVCM) less than $0.1 \%$, have a low potential for contaminating surrounding components or assemblies.

A number of investigators have studied the effects of space environments on material performance. . $^{5-18}$ However, only a limited number have researched seal materials. ${ }^{19-21}$ The objective of the work presented herein was to add to this body of knowledge by evaluating the characteristics of three silicone elastomers, including compression set, adhesion force between replicate samples, and the rate of leakage flow of seals. The performance of the elastomers after $\mathrm{AO}$ exposure and after $\mathrm{AO}$ and $\mathrm{UV}$ exposures was compared to their performance in the asreceived condition in order to quantify the effects of space environments.

\section{Description of the experiments}

\section{A. Specimens}

Three candidate elastomer compounds of different durometer values were evaluated in this study. Specimens were molded from three types of silicone elastomer compounds produced by two manufacturers. Each compound studied (Esterline ELA-SA-401, Parker Hannifin S0899-50 and Parker Hannifin S0383-70) was classified as lowoutgassing having TML less than $1.0 \%$ and CVCM less than $0.1 \%$, per ASTM E595. ${ }^{22}$ Measured values of TML and CVCM are listed in Table 1.

TABLE 1.-RESULTS OF OUTGAS TESTING ON THREE SILICONE ELASTOMER COMPOUNDS

\begin{tabular}{|l|c|c|c|}
\hline \multicolumn{1}{|c|}{ Compound } & Durometer A & $\begin{array}{c}\text { Total mass loss, } \\
(\%)\end{array}$ & $\begin{array}{c}\text { Collected volatile condensable materials, } \\
(\%)\end{array}$ \\
\hline ELA-SA-401 & 38 & 0.07 & 0.04 \\
\hline S0899-50 & 50 & 0.32 & 0.08 \\
\hline S0383-70 & 70 & 0.30 & 0.06 \\
\hline
\end{tabular}




\section{Specimens for Compression Set Tests}

Specimens for compression set tests were molded from the three silicone elastomer compounds into standard AS-568A size 2-309 o-ring form. For reference, the dimensions are shown in Table 2. Specimens were prepared consistent with the standard test protocol per ASTM D $395 .{ }^{23}$

TABLE 2.-NOMINAL DIMENSIONS OF AS-568A SIZE 2-309 O-RINGS

\begin{tabular}{|l|l|c|}
\hline \multicolumn{1}{|c|}{ Dimension } & Units & Value \\
\hline Outside diameter & $\mathrm{cm}$ (in.) & $2.11(0.832)$ \\
\hline Inside diameter & $\mathrm{cm}$ (in.) & $1.05(0.412)$ \\
\hline Thickness & $\mathrm{cm}$ (in.) & $0.533(0.210)$ \\
\hline
\end{tabular}

\section{Specimens for Elastomer-to-Elastomer Adhesion Tests}

Specimens for adhesion tests were fabricated from $0.53 \mathrm{~cm}(0.21$ in.) thick sheet material manufactured from the three silicone elastomer compounds. Specimens were cut from the sheet using a lubricated rotating punch to form a cylindrical specimen approximately $0.89 \mathrm{~cm}(0.35 \mathrm{in}$.) in diameter and $0.53 \mathrm{~cm}(0.21 \mathrm{in}$.$) thick. The$ specimens were not perfect cylinders due to the compliance of the elastomer sheet. The lowest durometer material specimens, ELA-SA-401, exhibited the greatest amount of taper in the cylindrical surface. For each trial, the contact areas of the specimens were measured to compensate for the variation in diameters. Prior to testing, any mold releasing agent or lubricant remaining on the specimens was removed by cleaning with isopropyl alcohol and air drying.

\section{Specimens for Leakage Flow Tests}

Specimens for leakage flow tests were standard AS-568A size 2-309 o-rings molded from the three silicone elastomer compounds. They were unmodified from their as-received condition beyond cleaning with isopropyl alcohol and air drying. The final design of the LIDS main interface seal has not been completed and is not likely to be a standard o-ring geometry. However, the o-rings were representative seals on which the influence of space environments was investigated.

\section{B. Space Environments Exposures}

The specimens were tested in their as-received condition, as well as after exposure to simulated space environments. Select specimens were exposed to AO and then tested. Additional tests were conducted on specimens that received both $\mathrm{AO}$ and subsequent $\mathrm{UV}$ exposure.

Specimens were cleaned prior to initial space environments exposure. After exposure to AO or UV, only compressed gas was used to remove any dust that may have settled on the specimens.

\section{Atomic Oxygen (AO) Exposure}

The specimens were exposed to AO in a directed beam facility located at NASA Glenn Research Center that used an electron cyclotron resonance plasma source operated on pure oxygen (Fig. 1). A brief description of the facility is presented for completeness and the details of the facility were given in the work by Stidham. ${ }^{24}$ The facility generated a directed thermal energy beam of $\mathrm{AO}$ with less than $1 \%$ ions at energies of typically 15 to $18 \mathrm{eV}$. The source operated at microwave energy $(2.45 \mathrm{GHz}, 1000 \mathrm{~W})$ and used to two large electromagnets for both dissociation of oxygen through electron collision and for beam focusing. The exposure was completed while the chamber was at vacuum pressure ( 0.03 to $0.1 \mathrm{~Pa}(0.2$ to $0.8 \mathrm{mTorr})$ ). In addition to producing $\mathrm{AO}$, the source also produced vacuum ultraviolet (VUV) radiation at $130 \mathrm{~nm}$ at an intensity of approximately 150 suns. Specimens were placed onto a circular plate that was mounted in the facility for exposure such that only the surfaces nearest the source were exposed to AO.

Five polymide Kapton $\mathrm{H}$ specimens were positioned to provide $\mathrm{AO}$ fluence measurements. Using spatial interpolation, the $\mathrm{AO}$ fluence of each individual elastomer specimen was determined through simultaneous exposure of the Kapton witness specimens per ASTM E2089. ${ }^{25}$ These specimens have well known erosion rates when exposed to $\mathrm{AO}$ and serve as a quantification method for exposure to $\mathrm{AO} .^{25}$ The witness specimens were placed in an 8 to $13 \mathrm{~Pa}$ (60 to $100 \mathrm{mTorr}$ ) vacuum for $48 \mathrm{hr}$ prior to and subsequent to AO exposure to fully dehydrate. The difference in mass of the polyimide Kapton was used to calculate the effective fluence using Eq. $1,{ }^{25}$ where $F$ was 


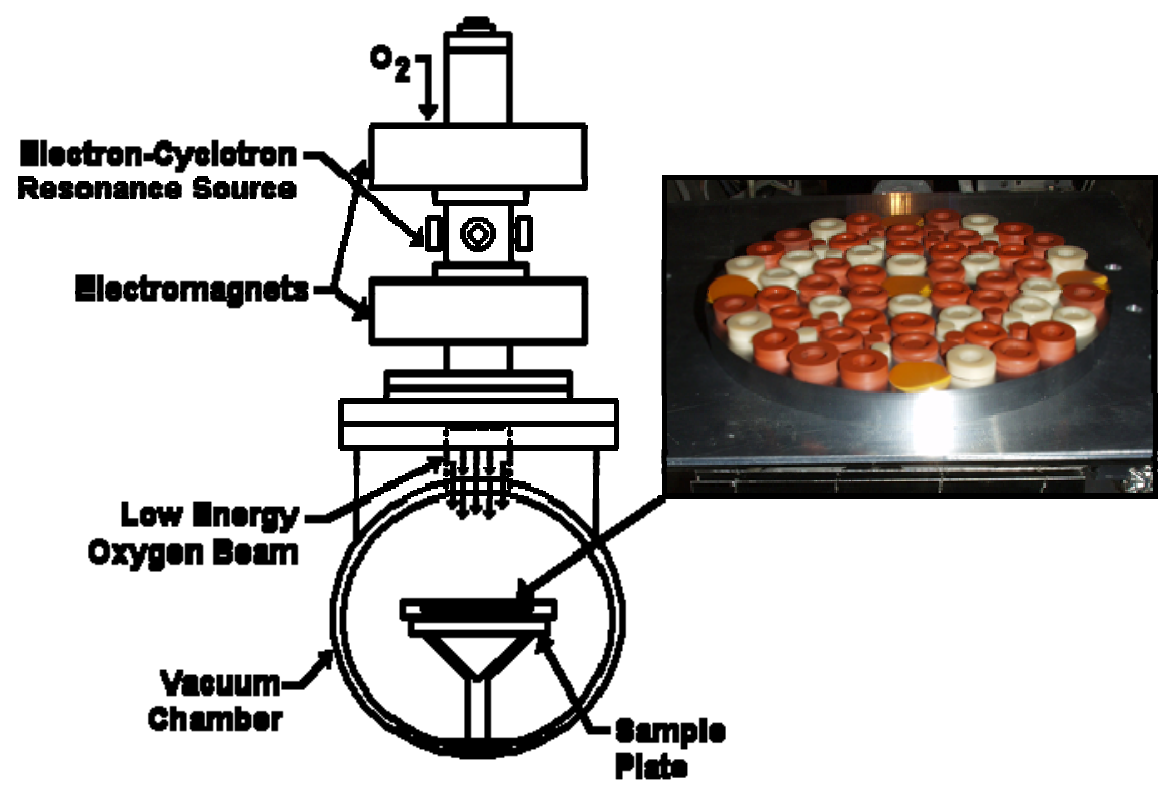

Figure 1.-AO exposure facility diagram and photograph of specimen plate.

$$
F=\frac{m}{A \cdot \rho \cdot E}
$$

the AO fluence (atoms $/ \mathrm{cm}^{2}$ ), $m$ was the mass loss of polyimide Kapton $\mathrm{H}(\mathrm{g}), A$ was the area of the polyimide Kapton $\mathrm{H}$ exposed to AO $\left(\mathrm{cm}^{2}\right)$, $\rho$ was the density of polyimide Kapton $\mathrm{H}\left(1.42 \mathrm{~g} / \mathrm{cm}^{3}\left(0.05 \mathrm{lbm} /\right.\right.$ in. $\left.\left.{ }^{3}\right)\right)$, and $E$ was the erosion yield for polyimide Kapton $\mathrm{H}$ in LEO $\left(3 \times 10^{-24} \mathrm{~cm}^{3} /\right.$ atom $\left.\left(1.83 \times 10^{-25} \mathrm{in}^{3} / \mathrm{atom}\right)\right)$.

\section{Ultraviolet (UV) Radiation Exposure}

Select specimens were exposed to UV to characterize the effects of several levels of UV on the three seal elastomers. Prior to UV exposure, the selected specimens were exposed to a level of AO fluence between $5.1 \times 10^{21}$ and $7.3 \times 10^{21}$ atoms $/ \mathrm{cm}^{2}\left(3.3 \times 10^{22}\right.$ and $4.7 \times 10^{22}$ atoms $/$ in. $\left.{ }^{2}\right)$. The specimens were subjected to UV exposure and then adhesion or leakage rate tested before receiving additional UV exposure and testing.

The specimens were simultaneously exposed to VUV and near ultraviolet (NUV) radiation in an exposure facility located at NASA Glenn Research Center. A brief description of the facility is presented for completeness and the details of the facility are given in the work by Dever. ${ }^{26}$

The facility uses a cryogenic vacuum pumping system to expose samples under high vacuum conditions. The specimens were subjected to a pressure of approximately $7 \times 10^{-4} \mathrm{~Pa}\left(5 \times 10^{-3} \mathrm{mTorr}\right)$ for $24 \mathrm{hr}$ before beginning the UV exposure. Separate sources of VUV and NUV were oriented orthogonal to one another. The sources illuminated the specimens placed on a plate (see Fig. 2) tilted approximately $30^{\circ}$ from vertical to receive simultaneous VUV and NUV exposure at levels similar to LEO, see Fig. 3.

The light source for VUV exposure was a 30-W deuterium lamp with a magnesium fluoride end-window, which provided a lower cut-off wavelength of $115 \mathrm{~nm}$. The VUV source was calibrated to determine the exposure intensity using a cesium iodide phototube sensitive in the 115 to $200 \mathrm{~nm}$ wavelength band. The VUV source was installed on a vacuum port that can be isolated from the specimen chamber. Every 48 to $72 \mathrm{hr}$, exposures were briefly interrupted while the VUV source was removed from the facility, cleaned, and re-calibrated, while the specimens remained under vacuum. The VUV source produced light primarily in the 115 to $200 \mathrm{~nm}$ wavelength band, but the output also included near ultraviolet wavelength light (up to $400 \mathrm{~nm}$ ). At wavelengths greater than $200 \mathrm{~nm}$, however, the near ultraviolet output was a small fraction of the Sun's intensity. 


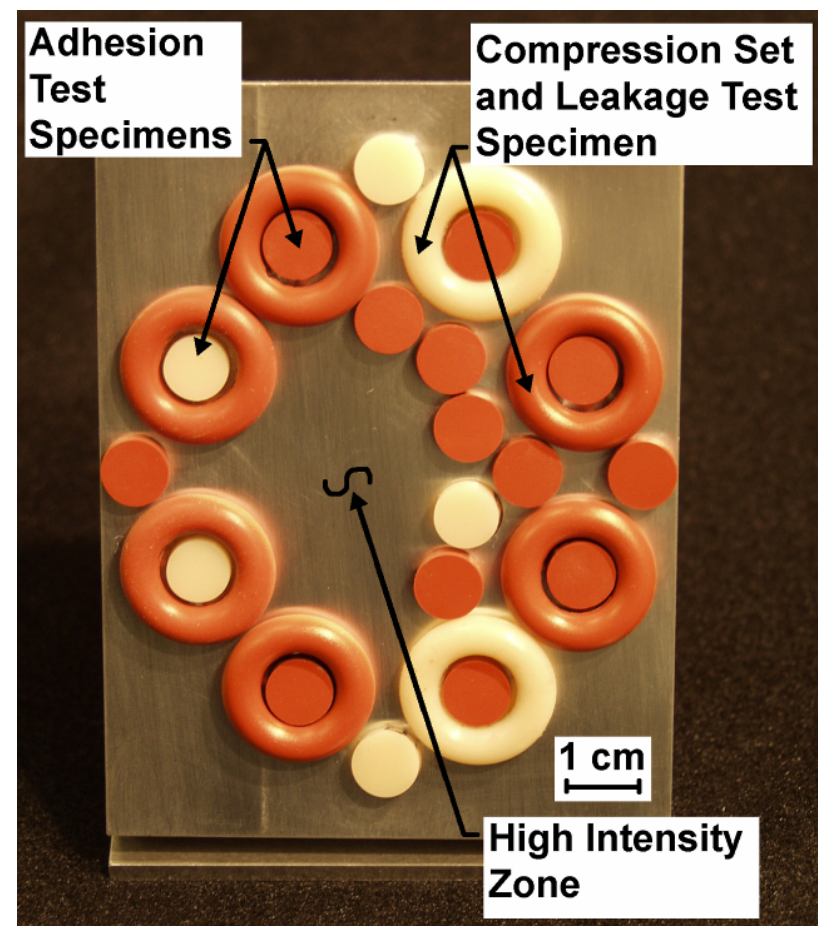

Figure 2.-Photograph of the UV exposure plate with elastomer specimens mounted.

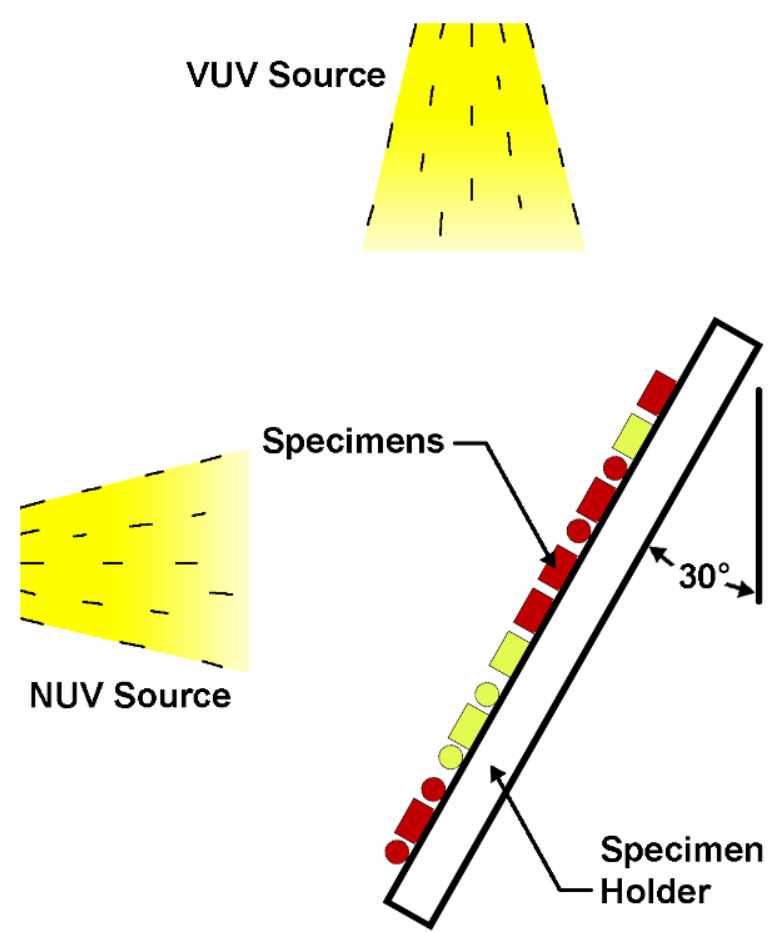

Figure 3.-Graphic depicting the orientation of the specimens in relation to the VUV and NUV light sources.

The light source for NUV exposure was a 500-W mercury (xenon) arc source which provided light in the 220 to $400 \mathrm{~nm}$ wavelength range. Since wavelengths above $220 \mathrm{~nm}$ transmit through air, the light source was located outside of the vacuum system and was transmitted through a quartz window. This NUV source was calibrated outside the facility before and after each exposure using a pyroelectric detector system and a $260 \mathrm{~nm}$ narrow bandpass filter. The manufacturer's spectral output curve for the NUV source and the $260 \mathrm{~nm}$ data were used to calculate the integrated intensity over the 220 to $400 \mathrm{~nm}$ wavelength range. Intensity experienced by the specimens was corrected for the transmittance through the quartz window and for the exposure plate angle.

Across the exposure plate, differences in NUV and VUV intensity were known. Specimens were arranged as to avoid areas of highest intensity, as can be seen in Fig. 2. Five separate UV exposures were conducted. For each exposure, the levels of NUV and VUV were not equivalent. By repositioning the specimens on the exposure plate for each test, adjustments were made to the total mean value of UV (average of NUV and VUV) exposure so as to maintain similar mean values for all specimens.

\section{Compression Set Tests}

The compression set of each elastomer o-ring was tested in accordance with ASTM specifications D395 Method $\mathrm{B}^{23}$ (for room and elevated temperature properties) and $\mathrm{D} 1229^{27}$ (for low temperature properties). A synopsis of the procedures is provided here for completeness.

A segment of the o-ring approximately $0.318 \mathrm{~cm}(0.125 \mathrm{in}$.) in length was removed from each of the 2-309 size o-ring specimens. Subsequently, the width and thickness of the specimens were measured according to ASTM D1414. ${ }^{28}$ The thickness of each o-ring was determined by averaging four thickness measurements per o-ring. The specimens were compressed to a total height of $75 \%( \pm 0.03 \mathrm{~mm}(0.001 \mathrm{in}$.)) of the average thickness measurement of the o-ring. The specimens remained at a constant displacement stress level at the test temperature for $70 \mathrm{hr}$. The o-ring specimens were allowed to recover for $30 \mathrm{~min}$ before the thickness of each specimen was measured. 


$$
C_{B}=\frac{\left(t_{o}-t_{i}\right)}{\left(t_{o}-t_{n}\right)} * 100
$$

The compression set, $C_{B}$, of each of the o-rings was calculated using the following equation, where $t_{o}$ was the original specimen thickness, $t_{i}$ was the final specimen thickness, and $t_{n}$ was the shim height.

The compression set tests were performed on the three silicone elastomers in the as-received condition at each $50,23,50$, and $125^{\circ} \mathrm{C}\left(-58,73,122\right.$, and $\left.257^{\circ} \mathrm{F}\right)$. In addition, the compression set of the elastomers was quantified in (1) the as-received condition, (2) following various levels of $\mathrm{AO}$ exposure, and (3) after exposure to approximately $6.0 \times 10^{21}$ atoms $/ \mathrm{cm}^{2}\left(3.9 \times 10^{22}\right.$ atoms $\left./ \mathrm{in}^{2}\right)$ of $\mathrm{AO}$ and various quantities of UV.

The standard method for measuring compression set of o-rings mandates that the median value of the three replicate samples tested for each case be reported. This study followed those recommendations for tests involving low and elevated temperature. However, this study deviated from that practice in room temperature tests involving specimens exposed to AO and UV by reporting the compression set value for each of the samples tested. The reason for this was that the exposure level of AO and UV was varied for each sample. Therefore, no three samples (from which the median would be computed) were exposed to identical levels of AO and UV.

\section{Adhesion Tests}

The force required to separate two specimens of similar elastomer compound was determined by compressing two specimens together by $25 \%$ of their combined height, holding for a period of time, and then separating them. The dwell periods were 1, 2, 4, 8, 16, and $24 \mathrm{hr}$ in succession using the same specimen pairs.

The elastomer specimen pairs were attached to metallic holders using cyanoacrylate adhesive and allowed to cure for $24 \mathrm{hr}$ before testing. One test specimen and its holder were attached to a stationary load cell. The other specimen and holder were attached to a movable platform, see Fig. 4. A servomotor was used to (1) move the platform to compress the specimens, (2) hold during the dwell period, and (3) move the platform to decompress the specimens. A linear variable displacement transformer (LVDT) was used to measure relative positions of the two elastomers. For all adhesion tests, the rate at which the specimen pairs were compressed together followed a prescribed function of the distance between the two specimen surfaces, see Fig. 5. The compression and decompression strokes were symmetric. In the figure, the dwell period occurs when position equals zero and corresponds to $25 \%$ compression of combined specimen height.

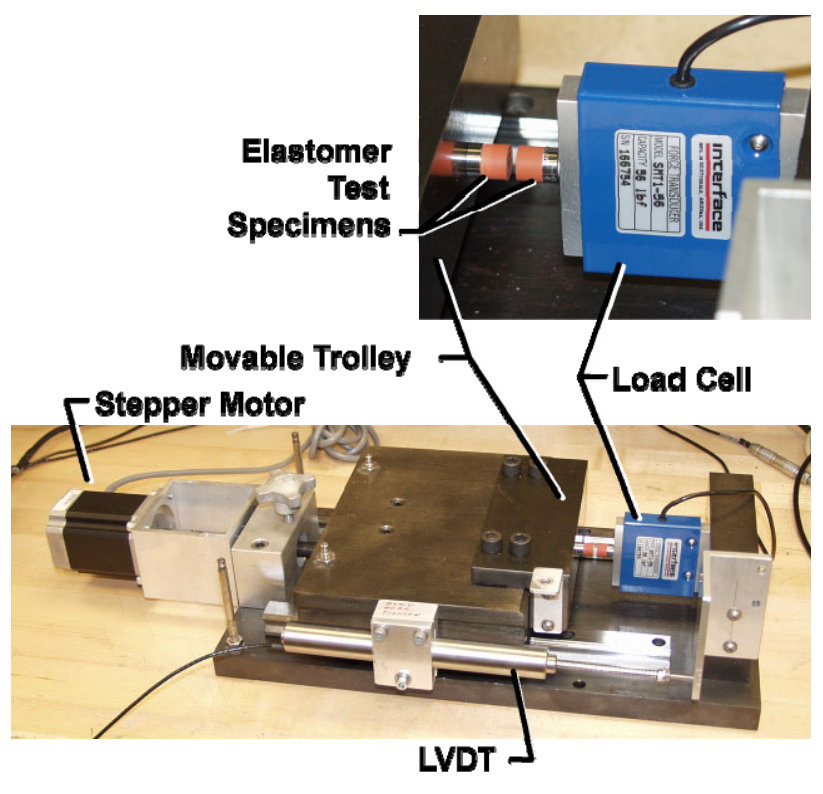

Figure 4.-Photograph of the adhesion test setup.

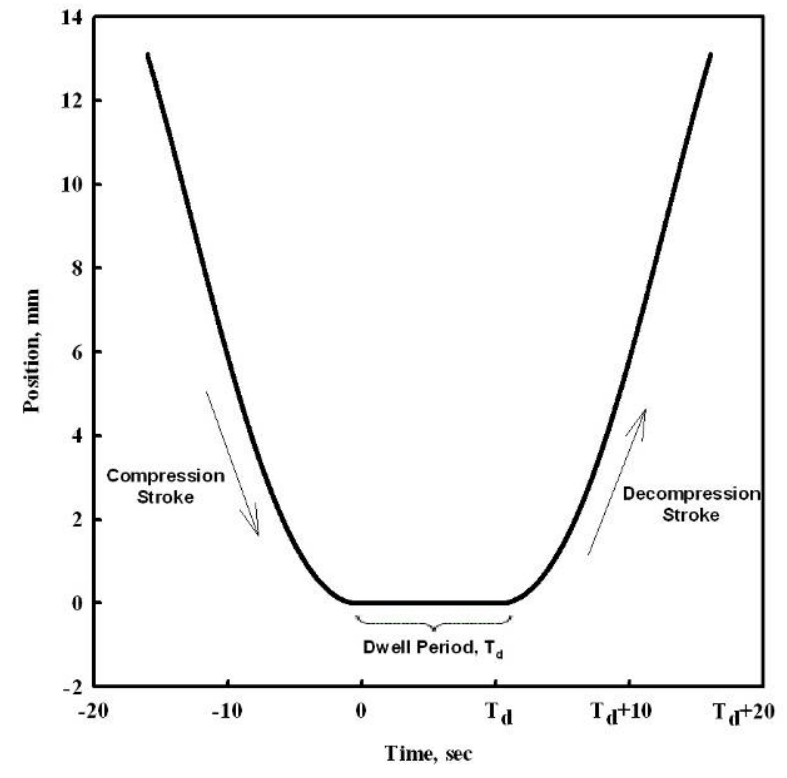

Figure 5.-Graph showing the rate of compression and decompression between two elastomer specimens during an adhesion test. 
The load cell was used to quantify the force during the compression, dwell, and decompression periods of the adhesion test. The load cell was calibrated and had an accuracy of $0.01 \mathrm{~kg}(0.03 \mathrm{lbf})$. Combined with the nominal $0.89 \mathrm{~cm}(0.35 \mathrm{in}$.) diameter of the test specimens, the accuracy of reported elastomer-to-elastomer adhesion stress was approximately $\pm 0.06 \mathrm{~N} / \mathrm{m}^{2}\left(9 \times 10^{-6} \mathrm{psi}\right)$. The adhesion results are presented in terms of stress (force divided by area) to account for any variation in the diameters of the specimens.

The adhesion between like compound elastomers was quantified at room temperature (1) in the as-received condition, (2) following exposure to various levels of $\mathrm{AO}$, and (3) after exposure to approximately $5.1 \times 10^{21}$ atoms $/ \mathrm{cm}^{2}\left(3.3 \times 10^{22}\right.$ atoms $/$ in. $\left.^{2}\right)$ of $\mathrm{AO}$ and various quantities of $\mathrm{UV}$.

\section{E. Leakage Flow Tests}

The leakage rate of the o-ring specimen was quantified using a pressure decay system. The system quantified any mass loss across the o-ring seal specimens, including the amount of dry air that passed through any leakage paths (e.g., through microcracks, between the o-ring to metal interface) and permeated through the specimens' elastomer compound.

The system consisted of a gas reservoir with known volume that was immersed in a water bath to moderate the temperature of the gas within the closed system, see Fig. 6 . The temperature of the water was monitored by two resistance temperature detectors (RTDs) with a combined accuracy of $\pm 0.08{ }^{\circ} \mathrm{C}\left(0.14{ }^{\circ} \mathrm{F}\right)$. Dry air was supplied to the gas reservoir at $101 \mathrm{kPa}(14.7 \mathrm{psia})$. The pressure in the gas reservoir was monitored using a differential pressure transducer. The pressure transducer provided $0.05 \%$ full-scale accuracy over a range of 0 to $100 \mathrm{kPa}$ ( 0 to $15 \mathrm{psid}$ ). The gas reservoir was connected to the test section containing the o-ring test specimen, see Fig. 7. External to the oring seal specimen, a rough vacuum pressure of approximately $20 \mathrm{~Pa}(150 \mathrm{mTorr})$ was applied and monitored by a vacuum pressure transducer with an accuracy of $1.07 \mathrm{~Pa}(8.03 \mathrm{mTorr})$.

The pressure decay system quantified the mass of gas within the system with time. To quantify the amount of gas within the system, gas pressure and temperature were monitored. Assuming an ideal gas, the mass loss or leakage rate, $\dot{m}$, was calculated from the following equation,

$$
\dot{m}=\frac{\Delta m}{\Delta t}=\frac{V}{R \cdot \Delta t}\left(\frac{p_{1}}{T_{1}}-\frac{p_{2}}{T_{2}}\right)
$$

where $m$ was the mass of the gas within the leakage quantification system, $t$ was time, $V$ was the closed volume, $p$ was absolute gas pressure, and $T$ was temperature. The subscripts denote two time steps (i.e., the beginning and end of the test). To ensure that the system of the supply lines from the gas reservoir to the test section is hermetic, the system was checked with a helium leak detection system and was found to leak no greater than $10^{-8} \mathrm{~cm}^{3} / \mathrm{sec}$ $\left(6.10 \times 10^{-10} \mathrm{in} .3 / \mathrm{sec}\right)$. Hence, any decrease in the mass of gas within the closed system was attributable to the test specimen leakage. Any leakage of o-rings containing the vacuum pressure did not alter the leakage measurements since the mass loss was calculated based upon the measurements of the closed volume containing the gas reservoir.

An uncertainty analysis was used to produce the error bars shown on the results graphs. The uncertainty analysis of Eq. 3 resulted in Eq. 4, where $u$ represents the uncertainty for the subscripted variable. The uncertainties for each variable within the equation, including calibration error, were estimated and combined using the root-sum-

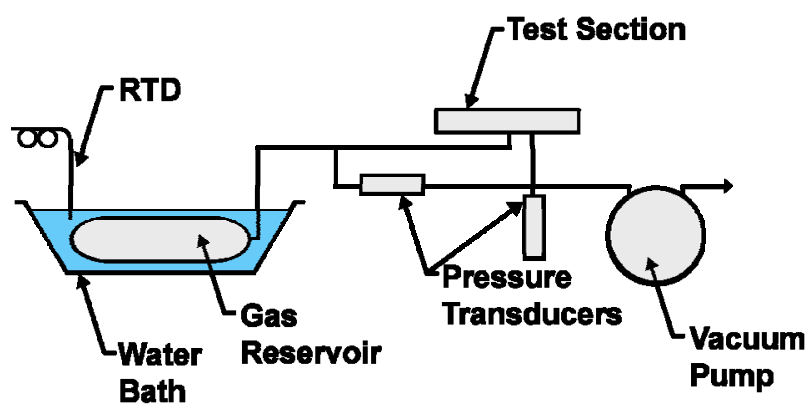

Figure 6.-Schematic of the pressure decay system.

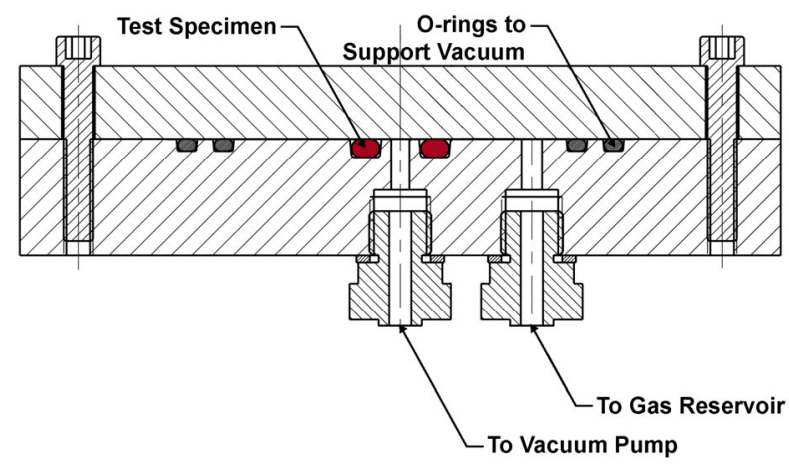

Figure 7.-Schematic of the pressure decay system test section. 
square method. The leakage rate uncertainty was computed for each individual specimen trial. Due to the variation in the pressure measurements for each individual trial (and less so for temperature variability), the size of the leakage rate error bars was different for each data point plotted.

$$
u_{\dot{m}}=\dot{m}\left\{\left(\frac{u_{V}}{V}\right)^{2}+2\left(\frac{u_{p}}{p_{1}-p_{2}}\right)^{2}+\left(p_{1}{ }^{2}+p_{2}{ }^{2}\right)\left(\frac{u_{T}}{T\left(p_{1}-p_{2}\right)}\right)^{2}\right\}^{1 / 2}
$$

The leakage rates of the silicone elastomer o-rings were quantified at room temperature (1) in the as-received condition, (2) following exposure to various levels of $\mathrm{AO}$, and (3) after exposure to approximately $5.8 \times 10^{21}$ atoms $/ \mathrm{cm}^{2}\left(3.7 \times 10^{22}\right.$ atoms $\left./ \mathrm{in}^{2}\right)$ of $\mathrm{AO}$ and various quantities of UV. The leakage rates after exposure to simulated space environments were meant to act as a method for quantifying the change in leakage rates after periods of various mission lengths.

\section{Results and Discussion}

\section{A. Compression Set}

The compression set of each of the three elastomer compounds was tested in the as-received condition at $-50,23,50$, and $125^{\circ} \mathrm{C}\left(-58,73,122\right.$, and $\left.257^{\circ} \mathrm{F}\right)$. The data for each test is tabularized in Appendix A. Per ASTM standards $^{23,27}$, the median compression set values of three repeated trials were recorded, see Fig. 8 . All of the elastomers exhibited the least amount of compression set at room to moderate temperatures, 23 to $50{ }^{\circ} \mathrm{C}$ ( 73 to $\left.122{ }^{\circ} \mathrm{F}\right)$, as compared with warm, $125^{\circ} \mathrm{C}\left(257^{\circ} \mathrm{F}\right)$ and refrigerated temperatures, $-50{ }^{\circ} \mathrm{C}\left(-58^{\circ} \mathrm{F}\right)$. The results showed that the ELA-SA-401 silicone elastomer compound exhibited the least amount of compression set at each of the temperatures tested and smallest variation between temperatures.

After exposure to AO, the compression set of each individual trial was measured, see Fig. 9. The erosion rates of the Kapton witness specimens varied over the exposure plate, indicating that the AO exposure varied for each specimen. Specimens received various levels of AO fluence ranging from $2.5 \times 10^{21}$ to $7.6 \times 10^{21}$ atoms $/ \mathrm{cm}^{2}\left(1.6 \times 10^{22}\right.$ to $4.9 \times 10^{22}$ atoms $/$ in. $^{2}$ ). The three elastomer compounds had similar values of compression set. The S0383-70, S0899-50, and ELA-SA-401 compounds exhibited average compression set values of 15.1, 13.5, and 15.9\%, respectively.

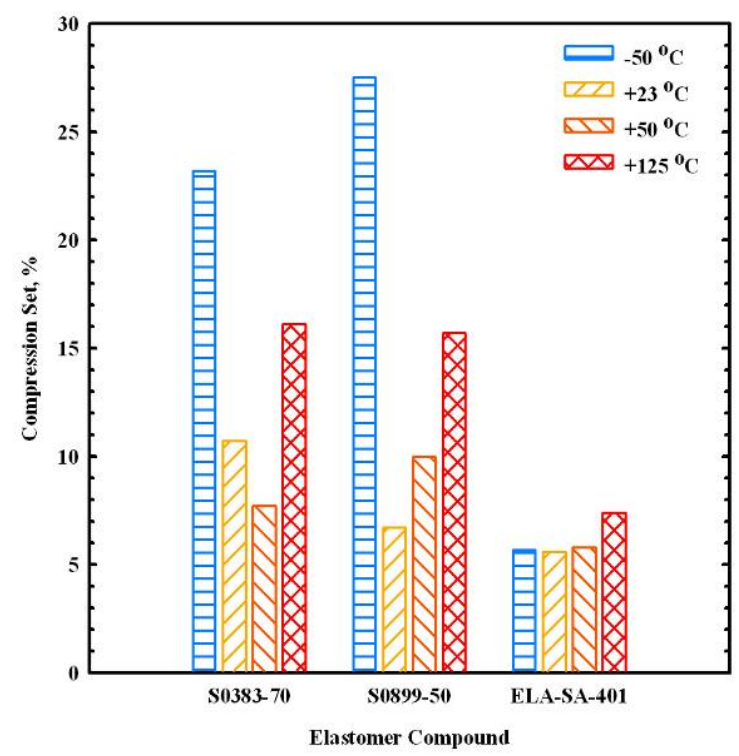

Figure 8.-Graph showing the effect of temperature on the compression set of three silicone elastomer compounds.

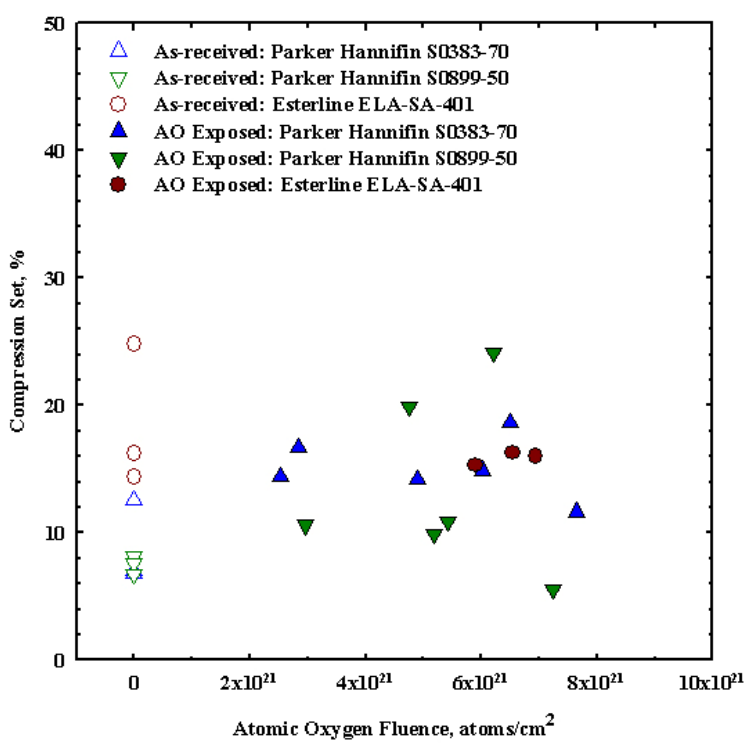

Figure 9.-Graph showing the effect of AO fluence on the compression set of three silicone elastomer compounds. 
A discrepancy in results exists between the two sets of compression set data for the ELA-SA-401 material. The investigation into the effect of temperature returned a median compression set value of $5.6 \%$ at $23{ }^{\circ} \mathrm{C}\left(73{ }^{\circ} \mathrm{F}\right)$, whereas the $\mathrm{AO}$ exposure study returned a median compression set value of $16.2 \%$ for similar test conditions in the as-received state of the material. The two sets of data were produced from two different batches of material. The tests were conducted at two different locations, using different facilities and instruments. Each location followed the same ASTM standard ${ }^{23}$, which mandates a contact type method used to measure the thickness, however, the standard does not prescribe the amount of force to be applied to the sample. As the ELA-SA-401 compound is very soft (38 durometer), small variations in this force will return different thickness measurements. To obtain identical results the measurement device and technique would have to be sensitive enough to apply an exact amount of force, which is not practical. Deviations from the standard, by using a non-contact method would greatly improve the accuracy and repeatability of the thickness measurements.

After exposure to $\mathrm{AO}$ and subsequently UV, the compression set for each of the compounds increased in comparison to specimens only exposed to AO, see Fig. 10. The ELA-SA-401 compound had the highest compression set. The S0899-50 and S0383-70 compounds exhibited lower compression set values. After exposure to AO and UV, the S0383-70, S0899-50, and ELA-SA-401 compounds exhibited average compression set values of $17.9,19.6$, and $27.1 \%$, respectively.

Statistical hypothesis analyses ${ }^{29}$ were performed to determine whether the individual data sets of the three materials were exposed to equivalent levels of (1) AO and (2) AO and UV. The details of the hypothesis analyses are shown in Appendix B. The mean exposure levels of the three material data sets were compared to the sample population mean value to determine if a valid comparison between data sets was permitted. The hypothesis tests confirmed, using a significance level of $\alpha=0.05$, that the mean exposure values of (1) AO and (2) AO and UV were not statistically different for the three materials. Therefore, comparisons of average compression set values were valid even though the exposure levels were not identical for each data point across the data sets. A summary of (1) the effects of AO and (2) the combined effects of AO and UV on the compression set of 2-309 size o-ring specimens molded from the three silicone elastomer compounds was shown in Fig. 11.

Excluding the discrepancy previously noted for the ELA-SA-401 material, the compression set increased with exposure to $\mathrm{AO}$ over the materials in the as-received condition. The increases in average compression set for the exposed S0383-70 and S0899-50 elastomers were $71 \%$ and $79 \%$ respectively. The average compression set for the exposed ELA-SA-401 decreased 14\%. This decrease can be attributed to the difficulty in measuring the compression set for very soft materials, in addition to the general experimental scatter.

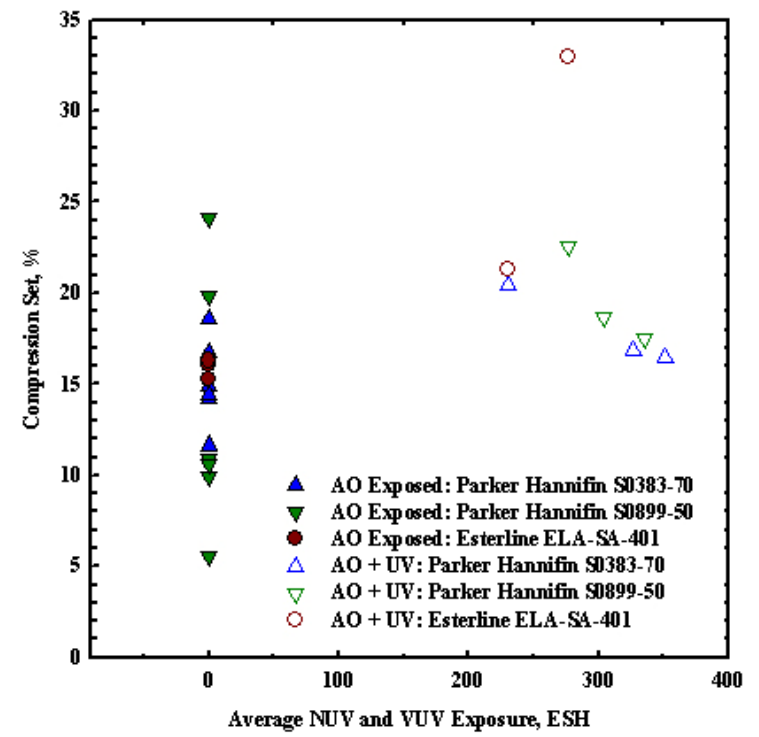

Figure 10.-Graph showing the effect of UV on the compression set of three silicone elastomer compounds previously exposed to AO.

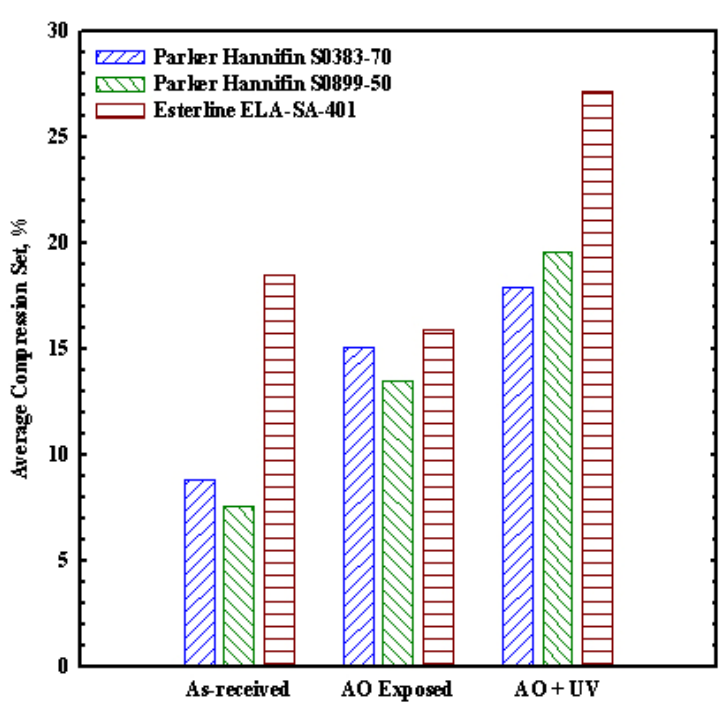

Figure 11.-Summary graph showing the effect of space environments exposures on the compression set of three silicone elastomer compounds. 
The exposure to UV further increased the compression set for each of the three materials studied. The average compression set values measured for the S0383-70, S0899-50, and ELA-SA-401 elastomers increased 19\%, 45\%, and $71 \%$ respectively compared with the AO exposed data set. When comparing the specimens exposed to both $\mathrm{AO}$ and UV with those in the as-received condition, the average compression set values increased $104 \%, 161 \%$, and 47\% (S0383-70, S0899-50, and ELA-SA-401 respectively) after space environment exposures.

\section{B. Elastomer-to-Elastomer Adhesion}

The results of a typical elastomer-to-elastomer adhesion test are shown in Fig. 12. The data for each test is tabularized in Appendix C. The figure shows the compression stroke, dwell period, and decompression stroke for a typical S0383-70 compound test. The stiffness of the material was highest on the first compression cycle, as indicated by the steep portion of the curve during the compression stroke of the 1 hour contact period. The material subsequently softened for each of the next cycles $(2,4,8,16$, and 24 dwell periods), and no apparent steady-state stiffness was evident. Each of the three elastomers exhibited loss of resiliency during the dwell periods of the tests. This is indicated in the figure by the vertical line of the dwell period. While being held at constant displacement, the resistive load of the elastomer pair decreased. During the decompression stroke of the test, the negative force value indicates that adhesion occurred between the specimen pair. The maximum adhesion values recorded for each of the tests are plotted in the subsequent graphs of this section.

As shown in Fig. 13, the S0899-50 compound had the highest adhesion stresses followed by S0383-70. The ELA-SA-401 exhibited the lowest adhesion stresses. After a 24 hour dwell period, the S0899-50 compound exhibited an average adhesion stress of $564 \mathrm{kPa}(81.7 \mathrm{psi})$ while the corresponding value for the ELA-SA-401 compound was $150 \mathrm{kPa}(21.8 \mathrm{psi})$.

Two competing factors contributed to the noted variation of adhesion with dwell period: (1) the duration of the contact, or dwell period, and (2) the number of contacts. As shown in Fig. 13, the amount of adhesion initially decreases when comparing the first and second periods of contact ( 1 and $2 \mathrm{hr}$ dwell periods). Since the specimen pairs were repeatedly held in contact, separated, and then held in contact for a longer period, the trend indicates that the adhesion stress is lower for increasing number of contacts. After the third contact ( $4 \mathrm{hr} \mathrm{dwell} \mathrm{period),} \mathrm{the}$ adhesion values increased indicating that the adhesion stress increases with increased contact duration, as was expected.

Select elastomer-to-elastomer adhesion specimens were exposed to AO as described in section II.B.1. and subsequently evaluated as to determine the effects of the exposure. As shown in Fig. 14, modest amounts of exposure to AO greatly decreased the amount of adhesion recorded. In the case of the ELA-SA-401 material, the

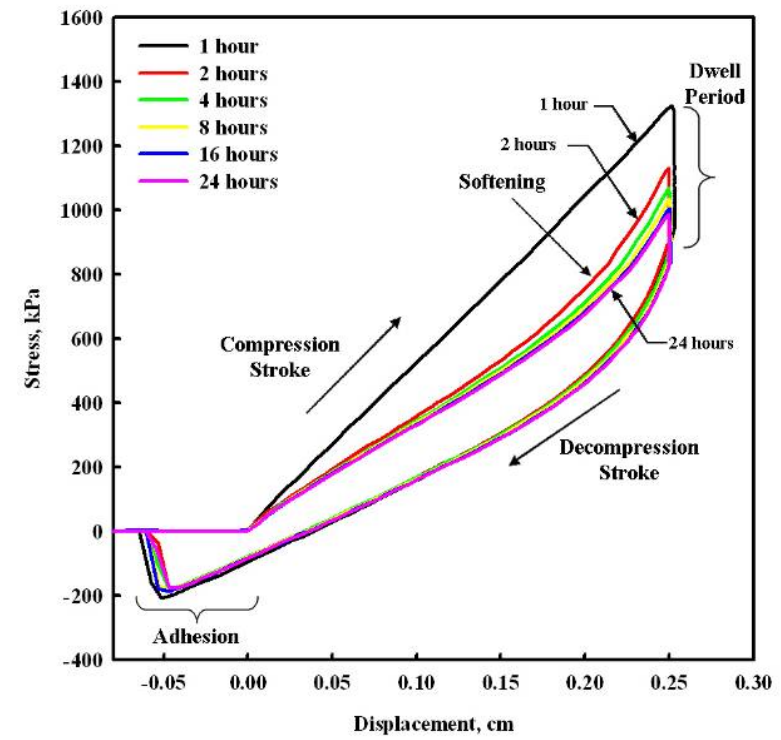

Figure 12.-Graph showing the effect of dwell period on the adhesion force for typical adhesion test.

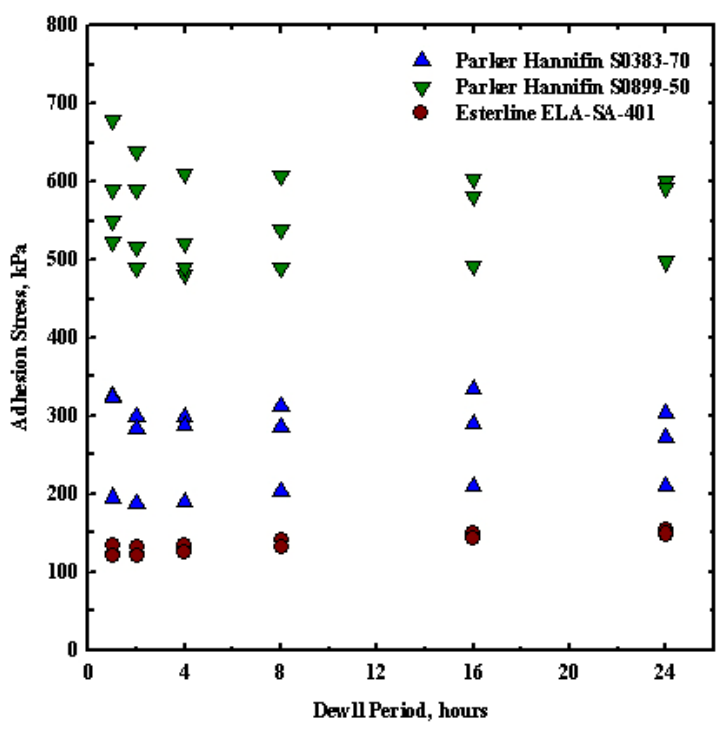

Figure 13.-Graph showing the effect of dwell period on the adhesion force of as-received three silicone elastomer compounds. 


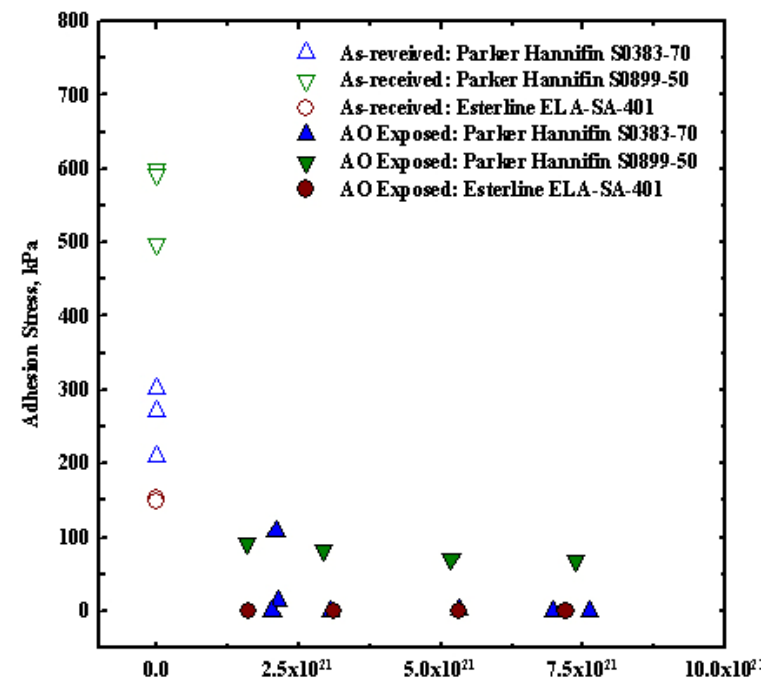

Figure 14.-Graph showing the effect of AO fluence on the elastomer-to-elastomer adhesion of three silicone elastomer compounds after $24 \mathrm{hr}$ dwell period.

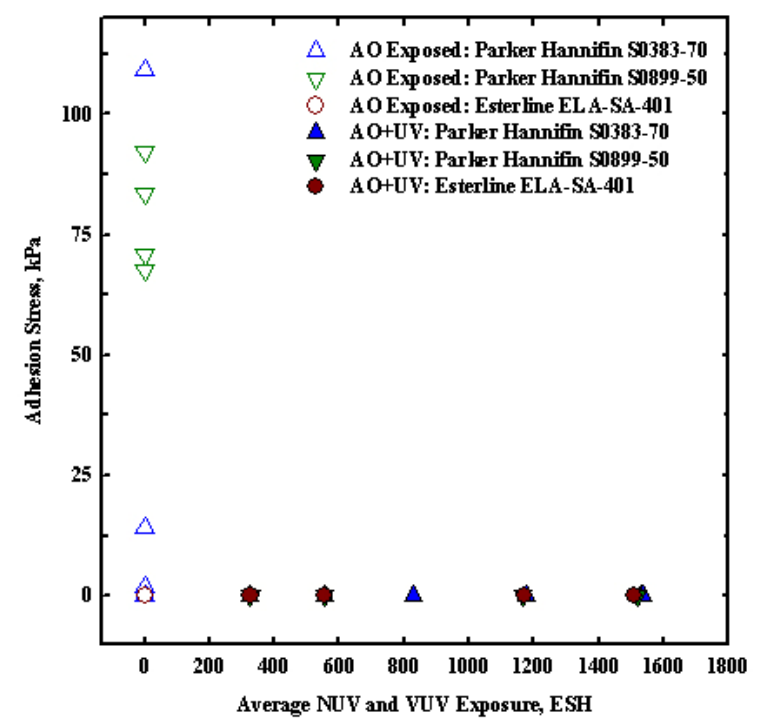

Figure 15.-Graph showing the effect of UV on the elastomer-to-elastomer adhesion after $24 \mathrm{hr}$ dwell period of three silicone elastomer compounds previously exposed to AO.

low levels of adhesion observed prior to $\mathrm{AO}$ exposure were reduced to levels below the resolution of the test apparatus's load cell. The high levels of adhesion observed in the S0899-50 material were reduced by more than $80 \%$.

The reduction in adhesion values after exposure to $\mathrm{AO}$ was expected. During exposure to AO, the oxygen replaced the methyl groups of the siloxane on the surface of the specimens. The result was a layer of $\mathrm{SiO}_{\mathrm{x}}$, where $x$ is between 2 and 4, on the surface of the specimens. Since the $\mathrm{SiO}_{\mathrm{x}}$ compounds are glass-like, the coated surface acts to reduce the adhesive nature of the specimens.

Select elastomer-to-elastomer adhesion specimens that were previously exposed to between $5.2 \times 10^{21}$ and $6.5 \times 10^{21}$ atoms $/ \mathrm{cm}^{2}\left(3.4 \times 10^{22}\right.$ to $4.2 \times 10^{22}$ atoms/in. $\left.{ }^{2}\right)$ were exposed to various amount of UV. As shown in Fig. 15 , after exposure to UV the elastomer-to-elastomer adhesion was reduced further. All of the elastomer-to-elastomer adhesion measurements were below the resolution of the test apparatus.

\section{Leakage Flow}

The leakage flow rates of the 2-309 size o-ring test specimens were measured in the as-received, post-atomic oxygen exposure, and post-atomic oxygen and UV exposure conditions. The data for each test is tabularized in Appendix D.

In the as-received condition, the average leakage rates of o-ring specimens molded from the highest durometer material, S0383-70, were the lowest $\left(6.1 \times 10^{-7} \mathrm{~kg} /\right.$ day $\left(1.4 \times 10^{-6} \mathrm{lbm} /\right.$ day $\left.)\right)$, see Fig. 16. The lowest durometer material, ELA-SA-401, exhibited the highest rate of flow, $1.3 \times 10^{-6} \mathrm{~kg} /$ day $\left(3.0 \times 10^{-6} \mathrm{lbm} /\right.$ day $)$. These results were expected as high durometer materials have a greater stiffness than low durometer materials and produce a higher reaction force for a given amount of compression. It is the reaction force that minimizes the leakage paths between the specimens and the groove containing the seal, thereby reducing the leakage flow rate.

After exposure to various amounts of $\mathrm{AO}$, the leakage flow rates were measured and plotted as a function of $\mathrm{AO}$ fluence, see Fig. 17. For fluence values up to $7.2 \times 10^{21}$ atoms $/ \mathrm{cm}^{2}\left(4.6 \times 10^{22}\right.$ atoms $\left./ \mathrm{in}^{2}\right)$, the exposure of the specimens to AO slightly increased the leakage flow rate. The average values of leakage flow rate of the S0383-70, S0899-50, and ELA-SA-401 compounds were $1.6 \times 10^{-6} \mathrm{~kg} /$ day $\left(3.5 \times 10^{-6} \mathrm{lbm} /\right.$ day $), 2.9 \times 10^{-6} \mathrm{~kg} / \mathrm{day}$ $\left(6.5 \times 10^{-6} \mathrm{lbm} /\right.$ day $)$, and $1.9 \times 10^{-6} \mathrm{~kg} /$ day $\left(4.2 \times 10^{-6} \mathrm{lbm} /\right.$ day $)$ respectively.

Two specimens of each of the three compounds that had been previously exposed to AO were selected to be exposed to UV. These previously untested specimens had AO fluence levels ranging from $5.1 \times 10^{21}$ to $7.3 \times 10^{21}$ atoms $/ \mathrm{cm}^{2}\left(3.3 \times 10^{22}\right.$ to $4.7 \times 10^{22}$ atoms $/$ in $\left.^{2}\right)$. Specimens with similar AO exposure levels, but no exposure 


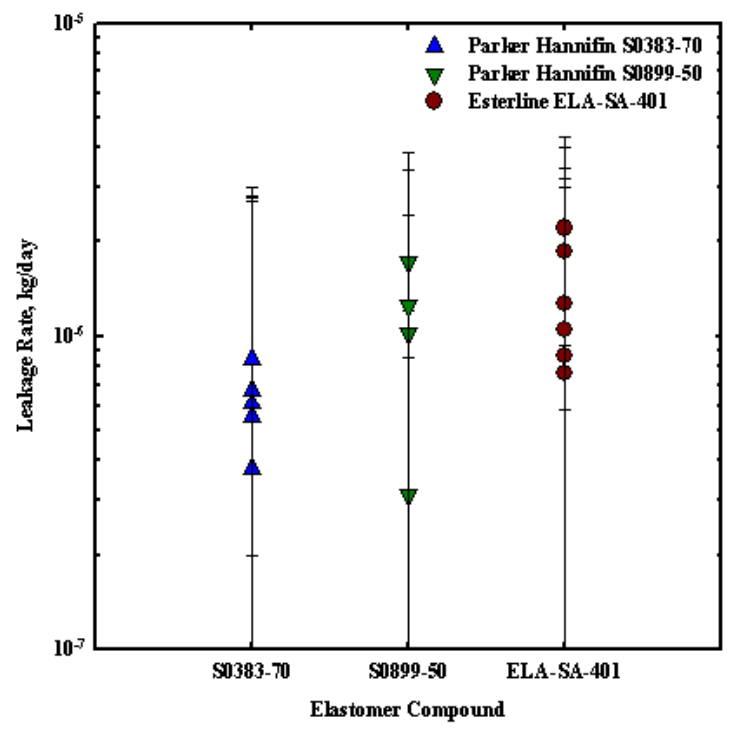

Figure 16.-Graph showing the leakage of 2-309 size o-ring specimens molded from three silicone elastomer compounds in the as-received condition.

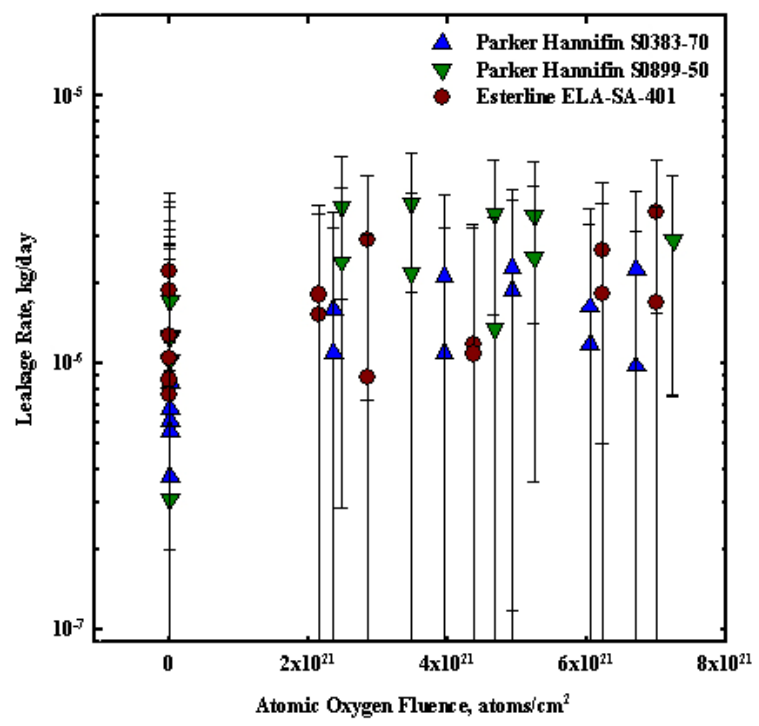

Figure 17.-Graph showing the effect of $A O$ fluence on the leakage flow rate of 2-309 size o-ring specimens molded from three silicone elastomer compounds.

to $\mathrm{UV}$, were shown at $\mathrm{UV}=0$ (Fig. 18) and had leakage rates ranging from $8.9 \times 10^{-7}$ to $4.0 \times 10^{-6} \mathrm{~kg} / \mathrm{day}\left(2.0 \times 10^{-6}\right.$ to $8.8 \times 10^{-6} \mathrm{lbm} /$ day). The previously untested specimens were exposed to approximately $325 \mathrm{ESH}$ of UV before being leakage tested. They were then exposed and leakage tested repeatedly until the total UV exposure was approximately $1500 \mathrm{ESH}$. The range of leakage rates increased to between $2.0 \times 10^{-5}$ and $9.0 \times 10^{-4} \mathrm{~kg} / \mathrm{day}\left(4.4 \times 10^{-5}\right.$ and $2.0 \times 10^{-3} \mathrm{lbm} /$ day) after approximately $1500 \mathrm{ESH}$ of exposure. The leakage flow rates of each of the three compounds were shown to have increased significantly with increased UV exposure.

The variation in leakage rates between the silicone elastomer compounds was significant. The S0899-50 compound exhibited the greatest amount of degradation to UV exposure. After exposure to $1500 \mathrm{ESH}$ of UV, the average leakage rate increased by a factor greater than 200 to $7.2 \times 10^{-4} \mathrm{~kg} /$ day $\left(1.6 \times 10^{-3} \mathrm{lbm} /\right.$ day $)$ when compared to specimens exposed to comparable levels of only AO. Comparing S0899-50 specimens exposed to approximately $1500 \mathrm{ESH}$ of UV with those specimens in the as-received condition, the average leakage rates increased by a factor of greater then 600. The leakage rates for the S0383-70 and ELA-SA-401 compound increased by a factors of approximately 100 and 50, repectively, when compared to specimens exposed to only AO (to an average of $6.0 \times 10^{-5} \mathrm{~kg} /$ day $\left(1.3 \times 10^{-4} \mathrm{lbm} /\right.$ day $)$ and $9.8 \times 10^{-5} \mathrm{~kg} /$ day $\left(2.2 \times 10^{-4} \mathrm{lbm} /\right.$ day $)$, respectively $)$.

Hypothesis analyses were calculated to ascertain the relevance of comparisons between data sets; the details of these analyses are shown in Appendix E. Using significance level of $\alpha=0.05$, the average AO fluence levels of the three data sets were not found to be statistically different; therefore the comparison of average leakage rates was appropriate. A summary of the effects of AO on the leakage rates of 2-309 size o-rings specimens molded from the three silicone elastomer compounds is shown in Fig. 19. The exposure to AO modestly increased the leakage flow rate above the as-received averages.

Analogous hypothesis analyses were conducted to determine the similarity of space environments exposure for combined AO and UV exposed specimens. The analyses showed that the AO and UV levels of the S0899-50 and ELA-SA-401 compounds were not statistically different; however, the total amounts of AO exposure and UV exposure to which the S0383-70 specimens were subjected were not statistically equivalent to the sample population mean. The average AO and UV exposures of the S0383-70 specimens were 13\% lower and 2\% higher, respectively, than the combined average of the S0899-50 and ELA-SA-401 exposure levels. Nevertheless, the leakage results of the S0383-70 were presented due to the similarity of exposure levels, while acknowledging the statistical deviation.

A summary of the effects of $\mathrm{AO}$ and the combined effects of AO and UV on the leakage rates of 2-309 size orings specimens molded from the three silicone elastomer compounds is shown in Fig. 19. As previously discussed, the exposure to $\mathrm{AO}$ modestly increased the leakage rates whereas significant leakage increase was observed with UV exposure. Since the hypothesis test showed that the levels of AO exposure of the two data sets (AO and the combined AO and UV) were similar, the leakage increase between these two data sets can be attributed only to the exposure to UV. 


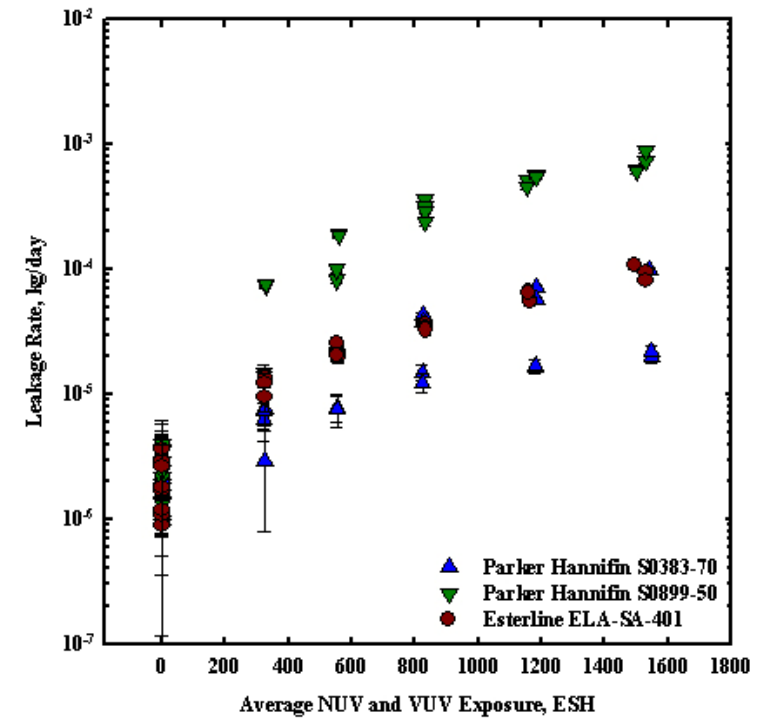

Figure 18.-Graph showing the effect of UV on flow rate of previously $\mathrm{AO}$ exposed 2-309 size o-ring specimens molded from three silicone elastomer compounds.

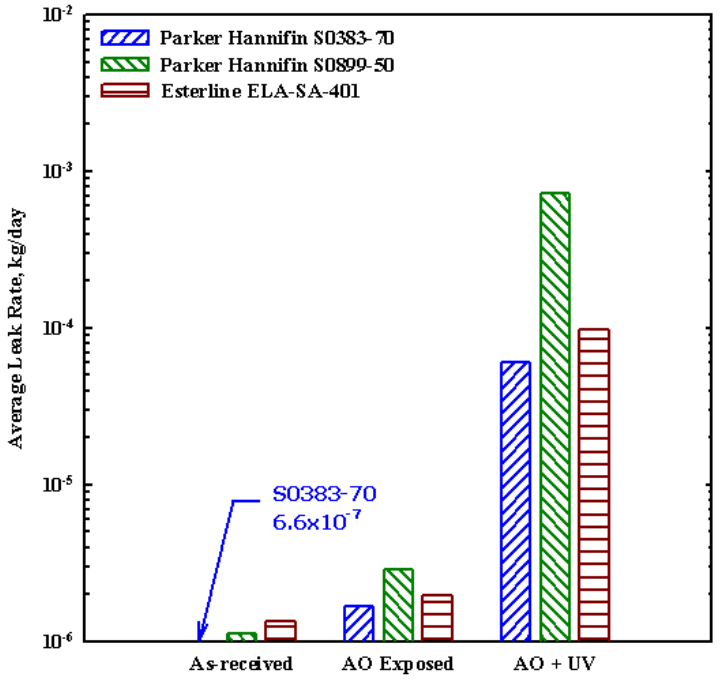

Figure 19.--Summary graph showing the effects of space environments exposures on the leakage flow rate of 2-309 size o-ring specimens molded from three silicone elastomer compounds.

\section{Conclusions}

The Low Impact Docking System (LIDS) is being designed to support all future space exploration missions to low-Earth orbit (LEO), to the Moon, and to Mars. The androgynous design of the LIDS requires that the gas seals of each module mate with the other in a seal-on-seal configuration. This unusual configuration of the seals requires an in-depth understanding of the behavior and characteristics of the elastomers that comprise the seals. Since the operating envelope will be mission specific, the effects of space environments must be understood. Select effects of temperature, solar radiation, reactive elements, and mission duration were discussed in this work. The seal characteristics of compression set, elastomer-to-elastomer adhesion, and o-ring leakage rate were investigated before and after exposure to simulated AO and UV space environments.

Based on the tests performed herein, the following observations were made.

(1) Each of the silicone elastomers compounds investigated, including Parker Hannifin compounds S0383-70 and S0899-50, and Kirkhill-TA ELA-SA-401, was characterized as low outgassing compounds meeting NASA's requirements.

(2) Each compound exhibited acceptable compression set over the LIDS operating environment of -50 to $50{ }^{\circ} \mathrm{C}$. The ELA-SA-401 compound exhibited the lowest compression set and variability over the operating temperature range.

(3) Compression set increased for each of the compounds with exposure to $\mathrm{AO}$ only, and furthermore with combined $\mathrm{AO}$ and $\mathrm{UV}$ exposures.

(4) In the as-received condition the ELA-SA-401 compound exhibited the lowest adhesion. The S0899-50 compound exhibited the highest adhesion. In general, adhesion increased with time held in contact under load.

(5) Exposure to modest levels of $\mathrm{AO}$ lowered the rates of adhesion for all of the compounds. A further decrease was recorded after subsequent UV exposure.

(6) Whereas the exposure to AO modestly increased the leakage flow rate, the UV exposure had a dramatic effect. Increases in leakage up to 600 times were measured after exposure to approximately $1500 \mathrm{ESH}$ of UV.

These results provide guidance for the applicability of these three silicone elastomer compounds for use in sealing systems exposed to space environments. 


\section{References}

${ }^{1}$ Lewis, J. L., Carroll; M. B., Morales; R. H., Le; T. D., National Aeronautics and Space Administration, Washington, DC, "Androgynous, reconfigurable closed loop feedback controlled low impact docking system with load sensing electromagnet capture system," U.S. Patent No. 6354540, (2002).

${ }^{2}$ Banks B.A., Miller S.K. and de Groh K.K., "Low Earth orbital atomic oxygen interactions with materials," AIAA-20045638. Also appears as NASA/TM-2004-213223, National Aeronautics and Space Administration, Glenn Research Center, August 2004

${ }^{3}$ de Pater, I. and Lissauer, J., Planetary Sciences, Cambridge University Press, 2001.

${ }^{4}$ Dobber, M.R., "GOME Moon measurements, including instrument characteristics and Moon albedo," 3rd ERS Symposium, Florence, Italy, pp. 743.

${ }^{5}$ Banks B.A. and Rutledge S.K., "Low Earth orbital atomic oxygen simulation for materials durability evaluation," $4^{\text {th }}$ European Symposium on Spacecraft Materials in Space Environment, Toulouse, France, September 6-9, 1988.

${ }^{6}$ Banks B.A., de Groh K.K. and Rutledge S.K., "Low Earth orbital atomic oxygen interactions with composite materials," Proceedings of the International Conference on Composites Engineering, New Orleans, LA, August 28-31, 1994.

${ }^{7}$ Banks B.A., de Groh K.K., Rutledge S.K. and Haytas C.A., "Consequences of atomic oxygen interaction with silicone and silicone contamination on surfaces in low Earth orbit," NASA/TM-1999-209179, National Aeronautics and Space Administration, Glenn Research Center, May 1999.

${ }^{8}$ Banks B.A., Miller S.K., de Groh K.K. and Demko R., "Atomic oxygen effects on spacecraft materials," NASA/TM-2003212484, National Aeronautics and Space Administration, Glenn Research Center, June 2003.

${ }^{9}$ de Groh K.K., Banks B.A. and Ma D., "Determination of ground-laboratory to in-space effective atomic oxygen fluence for DC 93-500 silicone," NASA/TM-2004-213389, National Aeronautics and Space Administration, Glenn Research Center, December 2004.

${ }^{10}$ Dever, J. A., de Groh, K. K., Banks, B. A., Townsend, J. A., "Effects of radiation and thermal cycling on Teflon FEP," High Performance Polymers, 11, No. 1, March 1999, pp. 123-140

${ }^{11}$ Dever, J., Messer, R., Powers, C., Townsend, J., Wooldridge, E., "Effects of vacuum ultraviolet radiation on thin polyimide films," High Performance Polymers, Volume 13, Number 3, September 2001, pp. S391-S399.

${ }^{12}$ Dever, J. A., de Groh, K. K., Messer R.K., McClendon M.W., Viens M., Wang L.L. and Gummow J.D., "Mechanical properties of Teflon ${ }^{\circledR}$ FEP retrieved from the Hubble Space Telescope," High Performance Polymers, Volume 13, Number 3, September 2001, pp. S373-S390.

${ }^{13}$ Dever, J. A., Charles Semmel, David Edwards, Russell Messer, Wanda Peters, Amani Carter and David Puckett, "Radiation durability of candidate polymer films for the next generation space telescope sunshield," AIAA 2002-1564, April 2002. Also appears as NASA/TM-2002-211508, National Aeronautics and Space Administration, Glenn Research Center, April 2002.

${ }^{14}$ Dever, J. A. and McCracken C. A., "Effects of vacuum ultraviolet radiation of various wavelength ranges on Teflon FEP film,” High Performance Polymers, Vol. 16, No. 2, June 2004, pp. 289-302.

${ }^{15}$ Dever, J. A., Banks, de Groh, K. K., and Miller, S. K., "Degradation of spacecraft materials," in Myer Kutz, ed., Handbook of Environmental Degradation of Materials, William Andrew Publishing, Norwich, New York, 2005.

${ }^{16}$ Dever, J. A., Banks, B. A., Yan., L., "Effects of vacuum ultraviolet radiation on DC93-500 silicone, Journal of Spacecraft and Rockets, Vol. 43, No. 2, March-April 2006, pp. 386-392.

${ }^{17}$ Dever, J. A., Miller, S. K., Sechkar, E. A., "Effects of the space environment on polymer film materials exposed on the Materials International Space Station Experiment (MISSE 1 and MISSE 2)," Proceedings of the 10th International Symposium on Materials in a Space Environment \& 8th International Conference on Protection of Materials and Structures in a Space Environment, Collioure, France, June 19 - 23, 2006.

${ }^{18}$ Snyder A., Banks B., Miller S., Stueber T. and Sechkar E., "Modeling of transmittance degradation caused by optical surface contamination by atomic oxygen reaction with adsorbed silicones," NASA/TM-2001-210597, National Aeronautics and Space Administration, Glenn Research Center, June 2001

${ }^{19}$ Pippin G., "Final report on analysis of Boeing specimens flown on the effects of space environment on materials experiment," Boeing Phantom Works, February 1999

${ }^{20}$ Christensen J.R., Underwood S.D., Kamenetzky R.R. and Vaughn J.A., “Atomic oxygen effects on seal leakage," $20^{\text {th }}$ Space Simulation Conference, United States, 1999

${ }^{21}$ Linton R.C., Finckenor M.M. Kamenetzky R.R. and Gray P., "Effects of atomic oxygen and ultraviolet radiation on candidate elastomeric materials for long-duration missions test series no. 1," NASA-TM-108408, National Aeronautics and Space Administration, George C. Marshall Space Flight Center, June 1993.

${ }^{22}$ ASTM E595-93 (Reapproved 2003), "Standard test method for total mass loss and collected volatile condensable materials from outgassing in a vacuum environment," ASTM International.

${ }^{23}$ ASTM D395-03, "Standard test methods for rubber property - compression set," ASTM International.

${ }^{24}$ Stidham, C. R., Stueber, T. J., Banks, B. A., Dever, J. A., Rutledge, S. K., and Bruckner, E. J., "Low Earth orbital atomic oxygen environment simulation facility for space materials evaluation," $38^{\text {th }}$ International SAMPE Symposium and Exhibition, SAMPE, Anaheim, CA, 1993.

${ }^{25}$ ASTM E2089-00, "Standard practices for ground laboratory atomic oxygen interaction evaluation of materials for space applications", ASTM International. 
${ }^{26}$ Dever, J.A., Pietromica, A. J., Stueber, T. J., Sechkar, E. A., and Messer, R. K. "Simulated space vacuum ultraviolet (VUV) exposure testing for polymer films," 39th Aerospace Sciences Meeting and Exhibit, AIAA-2001-1054, AIAA, Reno, NV, 2001.

${ }^{27}$ ASTM D1229-03, "Standard test method for rubber property - compression set at low temperature," ASTM International.

${ }^{28}$ ASTM D1414-94, "Standard test methods for rubber o-rings," ASTM International.

${ }^{29}$ dScheaffer, R.L., and McClave, J.T., Probability and Statistics for Engineers, Duxbury Press, 1995, pp. 426-428. 


\section{Appendix A \\ Compression Set Data}

1. Compression Set Data for Parker Hannifin S0383-70

As-received

$\begin{array}{ccccc}\text { ID } & \text { Compound } & \begin{array}{c}\text { AO Fluence } \\ \text { [atoms/cm }{ }^{2} \text { ] }\end{array} & \begin{array}{c}\text { Average UV } \\ \text { Exposure } \\ \text { [ESH] }\end{array} & \begin{array}{c}\text { Compression Set } \\ \text { [\%] }\end{array} \\ 309-1 & \text { S0383-70 } & 0 & 0 & 12.54 \\ 309-2 & \text { S0383-70 } & 0 & 0 & 6.85 \\ 309-3 & \text { S0383-70 } & 0 & 0 & 7.00\end{array}$

AO Exposure

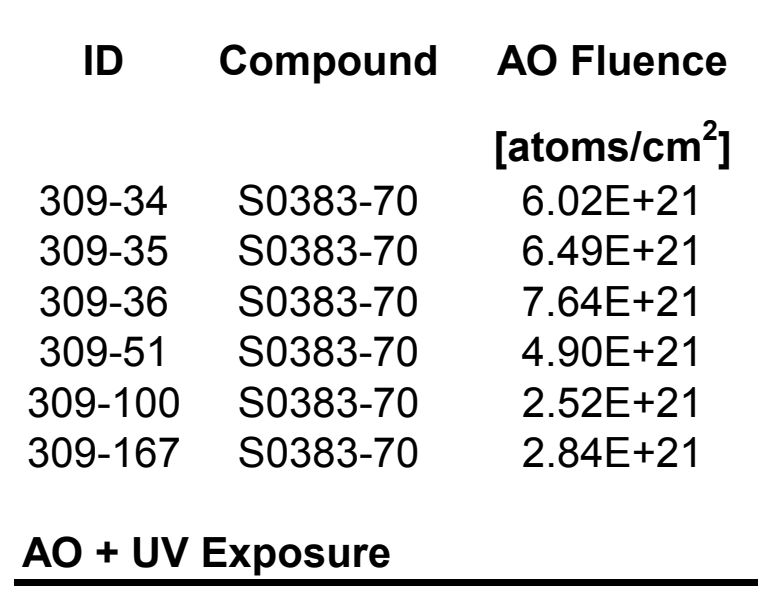

$\begin{array}{cc}\begin{array}{c}\text { Average UV } \\ \text { Exposure }\end{array} & \text { Compression Set } \\ \text { [ESH] } & {[\%]} \\ 0 & 14.90 \\ 0 & 18.63 \\ 0 & 11.65 \\ 0 & 14.21 \\ 0 & 14.40 \\ 0 & 16.72\end{array}$

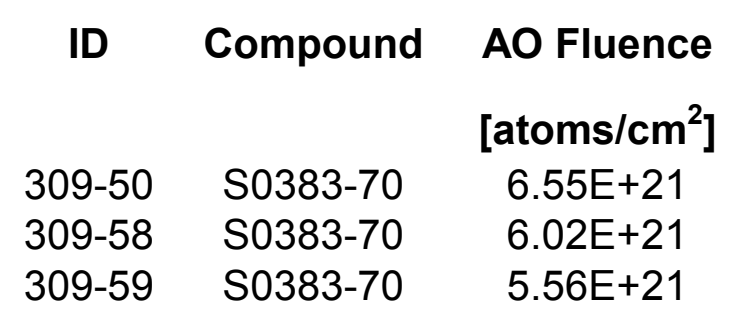

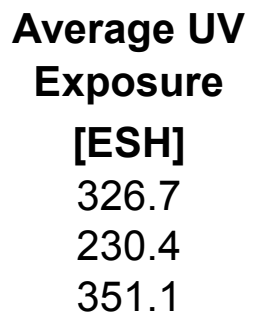

Compression Set

[\%]

16.85

20.45

16.44 
As-received

$\begin{array}{ccccc}\text { ID } & \text { Compound } & \begin{array}{c}\text { AO Fluence } \\ \text { [atoms/cm }{ }^{2} \text { ] }\end{array} & \begin{array}{c}\text { Average UV } \\ \text { Exposure } \\ \text { [ESH] }\end{array} & \begin{array}{c}\text { Compression Set } \\ \text { [\%] }\end{array} \\ 309-4 & \text { S0899-50 } & 0 & 0 & 8.20 \\ 309-5 & \text { S0899-50 } & 0 & 0 & 7.62 \\ 309-6 & \text { S0899-50 } & 0 & 0 & 6.75\end{array}$

AO Exposure

\begin{tabular}{|c|c|c|c|}
\hline ID & Compound & $\begin{array}{l}\text { AO Fluence } \\
\text { [atoms } / \mathrm{cm}^{2} \text { ] }\end{array}$ & $\begin{array}{c}\text { Average UV } \\
\text { Exposure } \\
\text { [ESH] }\end{array}$ \\
\hline 309-37 & S0899-50 & $6.22 \mathrm{E}+21$ & 0 \\
\hline 309-38 & S0899-50 & $5.41 \mathrm{E}+21$ & 0 \\
\hline 309-39 & S0899-50 & $7.25 \mathrm{E}+21$ & 0 \\
\hline $309-61$ & S0899-50 & $5.19 \mathrm{E}+21$ & 0 \\
\hline $309-170$ & S0899-50 & $4.76 \mathrm{E}+21$ & 0 \\
\hline $309-171$ & S0899-50 & $2.96 \mathrm{E}+21$ & 0 \\
\hline \multicolumn{4}{|c|}{ AO + UV Exposure } \\
\hline \multirow[t]{2}{*}{ ID } & Compound & AO Fluence & $\begin{array}{c}\text { Average UV } \\
\text { Exposure }\end{array}$ \\
\hline & & [atoms $/ \mathrm{cm}^{2}$ ] & {$[\mathrm{ESH}]$} \\
\hline $309-52$ & S0899-50 & $6.50 \mathrm{E}+21$ & 304.2 \\
\hline $309-53$ & S0899-50 & $5.42 \mathrm{E}+21$ & 276.8 \\
\hline $309-54$ & S0899-50 & $6.69 \mathrm{E}+21$ & 335.4 \\
\hline
\end{tabular}

Compression Set

[\%]

24.12

10.89

5.56

9.91

19.86

10.62 


\section{As-received}

$\begin{array}{llccc}\text { ID } & \text { Compound } & \begin{array}{c}\text { AO Fluence } \\ \text { [atoms/cm }{ }^{2} \text { ] }\end{array} & \begin{array}{c}\text { Average UV } \\ \text { Exposure } \\ \text { [ESH] }\end{array} & \text { Compression Set } \\ \text { 309-7 } & \text { XELA-SA-401 } & 0 & 0 & {[\%]} \\ 309-8 & \text { XELA-SA-401 } & 0 & 0 & 14.42 \\ 309-9 & \text { XELA-SA-401 } & 0 & 0 & 16.20 \\ & & & & 24.79 \\ \text { AO Exposure } & \end{array}$

$\begin{array}{ccc}\text { ID } & \text { Compound } & \begin{array}{c}\text { AO Fluence } \\ \text { [atoms/cm }\end{array} \\ & & \\ 309-40 & \text { XELA-SA-401 } & 5.89 \mathrm{E}+21 \\ 309-41 & \text { XELA-SA-401 } & 6.94 \mathrm{E}+21 \\ 309-42 & \text { XELA-SA-401 } & 6.55 \mathrm{E}+21 \\ & \\ \text { AO + UV Exposure }\end{array}$

Average UV Exposure [ESH]

0

0

0
Compression Set

[\%]

15.30

16.02

16.30

$\begin{array}{cccc}\text { ID } & \text { Compound } & \begin{array}{c}\text { AO Fluence } \\ \text { [atoms/cm }{ }^{2} \text { ] }\end{array} & \begin{array}{c}\text { Average UV } \\ \text { Exposure } \\ \text { [ESH] }\end{array} \\ 309-56 & \text { XELA-SA-401 } & 5.63 \mathrm{E}+21 & 230.4 \\ 309-57 & \text { XELA-SA-401 } & 5.77 \mathrm{E}+21 & 276.8\end{array}$

Compression Set

[\%]

21.33

32.94 
4. Compression Set Data for Compound in the As-Received Condition Tested at Various Temperatures

As-received

ID Compound Temperature

[deg C]

551-553 S0383-70

$-50$

554-556 S0383-70

23

557-559 S0383-70

50

560-562 S0383-70

125

563-565 S0899-50

$-50$

566-568 S0899-50

23

569-571 S0899-50

50

$572-574$ S0899-50

125

575-577 XELA-SA-401

$-50$

578-580 XELA-SA-401

23

581-583 XELA-SA-401

50

584-586 XELA-SA-401

125

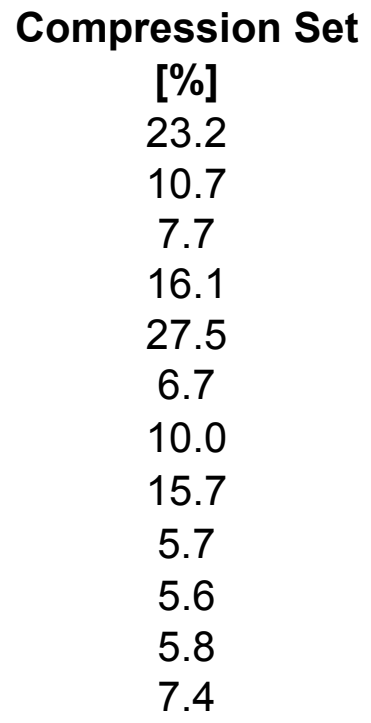


5. VUV and NUV Components of Average UV Values

Parker Hannifin S0383-70

\begin{tabular}{|c|c|c|}
\hline ID & $\begin{array}{c}\text { VUV } \\
\text { [ESH] }\end{array}$ & $\begin{array}{c}\text { NUV } \\
\text { [ESH] }\end{array}$ \\
\hline $309-50$ & 294.9 & 358.5 \\
\hline $309-58$ & 177.1 & 283.7 \\
\hline $309-59$ & 451.8 & 250.4 \\
\hline \multicolumn{3}{|c|}{ Parker Hannifin S0899-50 } \\
\hline ID & $\begin{array}{c}\text { VUV } \\
\text { [ESH] }\end{array}$ & $\begin{array}{c}\text { NUV } \\
\text { [ESH] }\end{array}$ \\
\hline $309-52$ & 294.9 & 358.5 \\
\hline $309-53$ & 269.1 & 284.4 \\
\hline $309-54$ & 404.6 & 266.2 \\
\hline \multicolumn{3}{|c|}{ Esterline ELA-SA-401 } \\
\hline ID & $\begin{array}{c}\text { VUV } \\
\text { [ESH] }\end{array}$ & $\begin{array}{c}\text { NUV } \\
\text { [ESH] }\end{array}$ \\
\hline $309-56$ & 177.1 & 283.7 \\
\hline $309-57$ & 269.1 & 284.4 \\
\hline
\end{tabular}





\section{Appendix B \\ Hypothesis Testing of Compression Set Data}

\section{Theory}

The authors used hypothesis testing to analyze the compression set data. As each of the specimens were exposed to unique levels of (1) AO and (2) AO and UV, a statistical approach was used to confirm the validity of comparisons of average compression set values across the three materials for each condition. Statistical hypothesis analyses were performed to determine whether the individual data sets of the three materials were exposed to equivalent levels of $\mathrm{AO}$ and $\mathrm{AO} \& \mathrm{UV}$.

The authors assumed that the distribution about the population mean was normally distributed such that the confidence interval could be stated according to equation (C1):

$$
\bar{X} \pm t_{\alpha / 2} S / \sqrt{n}
$$

where:
$\bar{X} \quad$ the population mean
$t \quad$ the student $\mathrm{t}$-value at a specified value of $\alpha$ for $\mathrm{t}$-distribution with $(n-1)$ degrees of freedom
$\alpha \quad$ the significance level
$S \quad$ the standard deviation of the sample measurements
$n \quad$ the sample size

The authors further assumed that the mean of the sample, $\mu_{0}$, was contained within the confidence interval. The authors tested this assumption using the hypothesis testing techniques. ${ }^{29}$ If the resulting confidence interval, $t_{\alpha / 2} S / \sqrt{n}$, did not contain $\mu_{0}$, then the hypothesis was rejected. If $\mu_{0}$ was within the confidence interval, then the hypothesis could not be rejected. Therefore, the hypothesized value $\mu_{0}$ would be rejected if

$$
|T|=\left|\frac{\bar{X}-\mu_{0}}{S / \sqrt{n}}\right|>t_{\alpha / 2}
$$

\section{Application}

The above theory was used in the analysis of results of small scale compression set results of three candidate elastomers: Parker S0383-70, Parker S08998-50, and XELA-SA-401, denoted 70, 50, and 38, respectively. Each of the materials was tested in three different conditions: (1) as-received, (2) after AO exposure, and (3) subsequent to AO and UV exposures. In conditions (2) and (3) the exposure levels to AO and/or UV were varied for each sample, thereby motivating this hypothesis analysis.

The mean exposure levels of the three material data sets were compared to the sample population mean value using a significance level of $\alpha=0.05$. The performed calculations, along with explanation of terms are shown below.

\section{Condition (2): AO Exposures}

The population mean $\bar{X}$ (the average of AO exposure levels for the there material data sets) was calculated to be $5.44 \times 10^{21}$ atoms $/ \mathrm{cm}^{2}$. Using equation (C2) with $\mu_{0}$ being the average level of AO exposure for each particular material, the analysis was performed as presented along with the corresponding value of $t$ for $\alpha=0.05(95 \%$ confidence):

$\mathrm{AO}_{70}:\left|\frac{\bar{X}-\mu_{0}}{S / \sqrt{n}}\right|=\left|\frac{5.44 \times 10^{21}-5.07 \times 10^{21}}{2.05 \times 10^{21} / \sqrt{6}}\right|=0.443<t_{\alpha / 2}=3.365$ 
$\mathrm{AO}_{50}:\left|\frac{\bar{X}-\mu_{0}}{S / \sqrt{n}}\right|=\left|\frac{5.44 \times 10^{21}-5.30 \times 10^{21}}{1.44 \times 10^{21} / \sqrt{6}}\right|=0.237<t_{\alpha / 2}=3.365$
$\mathrm{AO}_{38}:\left|\frac{\bar{X}-\mu_{0}}{S / \sqrt{n}}\right|=\left|\frac{5.44 \times 10^{21}-6.46 \times 10^{21}}{5.30 \times 10^{20} / \sqrt{3}}\right|=3.340<t_{\alpha / 2}=4.303$

The above calculations confirm that the mean exposure values of $\mathrm{AO}$ were not statistically different for the three materials tested in condition (2). This confirms the validity of comparisons of average compression set values for these materials, as shown in Fig. 9.

\section{Condition (3): $A O$ and UV Exposures}

The AO population mean was calculated to be $\bar{X}=6.02 \times 10^{21}$ atoms $/ \mathrm{cm}^{2}$, while the UV population mean was $\bar{X}=291.5$ ESH. Similarly as in condition (2) calculations, equation (C2) was used for analysis of average AO and average UV exposures.

$$
\begin{aligned}
& \mathrm{AO}_{70}:\left|\frac{\bar{X}-\mu_{0}}{S / \sqrt{n}}\right|=\left|\frac{6.02 \times 10^{21}-6.04 \times 10^{21}}{4.96 \times 10^{20} / \sqrt{3}}\right|=0.087<t_{\alpha / 2}=4.303 \\
& \mathrm{AO}_{50}:\left|\frac{\bar{X}-\mu_{0}}{S / \sqrt{n}}\right|=\left|\frac{6.02 \times 10^{21}-6.20 \times 10^{21}}{6.85 \times 10^{20} / \sqrt{3}}\right|=0.473<t_{\alpha / 2}=4.303 \\
& \mathrm{AO}_{38}:\left|\frac{\bar{X}-\mu_{0}}{S / \sqrt{n}}\right|=\left|\frac{6.02 \times 10^{21}-5.70 \times 10^{21}}{1.03 \times 10^{20} / \sqrt{2}}\right|=4.345<t_{\alpha / 2}=12.706 \\
& \mathrm{UV}_{70}:\left|\frac{\bar{X}-\mu_{0}}{S / \sqrt{n}}\right|=\left|\frac{291.5-302.7}{63.8 / \sqrt{3}}\right|=0.306<t_{\alpha / 2}=4.303 \\
& \mathrm{UV}_{50}:\left|\frac{\bar{X}-\mu_{0}}{S / \sqrt{n}}\right|=\left|\frac{291.5-305.5}{29.3 / \sqrt{3}}\right|=0.826<t_{\alpha / 2}=4.303 \\
& \mathrm{UV}_{38}:\left|\frac{\bar{X}-\mu_{0}}{S / \sqrt{n}}\right|=\left|\frac{291.5-253.6}{32.8 / \sqrt{2}}\right|=0.1 .635<t_{\alpha / 2}=12.706
\end{aligned}
$$

The above calculations confirm that the mean exposure values of UV were not statistically different for the three materials tested in condition (3). Similarly, the analyses have shown that the AO levels of the three compounds were not statistically different.

\section{Combined Conditions (2) and (3)}

In order to quantify the overall effect of space environment exposure (both $\mathrm{AO}$ and $\mathrm{AO}$ with UV) on the three candidate compounds, confirmation that the individual data sets of the materials in conditions (2) and (3) were exposed to statistically equivalent levels of $\mathrm{AO}$ was required. The mean $\mathrm{AO}$ exposure levels of the three material data sets in the two conditions were compared to the sample population mean value using a significance level of $\alpha=$ 0.05 . The AO population mean was calculated to be $\bar{X}=5.64 \times 10^{21}$ atoms $/ \mathrm{cm}^{2}$. Application of equation (C2) leads to the following calculations and results:

$\mathrm{AO}_{70}$ condition (2): $\left|\frac{\bar{X}-\mu_{0}}{S / \sqrt{n}}\right|=\left|\frac{5.64 \times 10^{21}-5.07 \times 10^{21}}{2.05 \times 10^{21} / \sqrt{6}}\right|=0.683<t_{\alpha / 2}=3.365$ 
$\mathrm{AO}_{50}$ condition (2): $\left|\frac{\bar{X}-\mu_{0}}{S / \sqrt{n}}\right|=\left|\frac{5.64 \times 10^{21}-5.30 \times 10^{21}}{1.44 \times 10^{21} / \sqrt{6}}\right|=0.577<t_{\alpha / 2}=3.365$

$\mathrm{AO}_{38}$ condition (2): $\left|\frac{\bar{X}-\mu_{0}}{S / \sqrt{n}}\right|=\left|\frac{5.64 \times 10^{21}-6.46 \times 10^{21}}{5.30 \times 10^{20} / \sqrt{3}}\right|=2.683<t_{\alpha / 2}=4.303$

$\mathrm{AO}_{70}$ condition (3): $\left|\frac{\bar{X}-\mu_{0}}{S / \sqrt{n}}\right|=\left|\frac{5.64 \times 10^{21}-6.04 \times 10^{21}}{4.96 \times 10^{20} / \sqrt{3}}\right|=1.402<t_{\alpha / 2}=4.303$

$\mathrm{AO}_{50}$ condition (3): $\left|\frac{\bar{X}-\mu_{0}}{S / \sqrt{n}}\right|=\left|\frac{5.64 \times 10^{21}-6.20 \times 10^{21}}{6.85 \times 10^{20} / \sqrt{3}}\right|=1.425<t_{\alpha / 2}=4.303$

$\mathrm{AO}_{38}$ condition (3): $\left|\frac{\bar{X}-\mu_{0}}{S / \sqrt{n}}\right|=\left|\frac{5.64 \times 10^{21}-5.70 \times 10^{21}}{1.03 \times 10^{20} / \sqrt{2}}\right|=0.810<t_{\alpha / 2}=12.706$

Based on the above analysis, the mean levels of AO exposure among the specimens tested in conditions (2) and (3) were not statistically different, with a confidence level of $95 \%$. Therefore, the change in average compression set values between conditions (2) and (3) can be solely attributed to UV exposure effects only (Figs. 10 and 11), since the average $\mathrm{AO}$ levels have been shown to be not statistically different. 



\section{Appendix C \\ Elastomer-to-Elastomer Adhesion Data}

1. Elastomer-to-Elastomer Adhesion Data for Parker Hannifin S0383-70

As-Received

\begin{tabular}{|c|c|c|c|c|c|c|c|c|c|c|c|c|}
\hline \multirow[t]{2}{*}{ ID \#1 } & \multirow[t]{2}{*}{ ID \#2 } & \multirow[t]{2}{*}{ Compound } & \multicolumn{2}{|c|}{$\begin{array}{l}\text { AO Fluence } \\
\text { [atoms } / \mathrm{cm}^{2} \text { ] }\end{array}$} & \multicolumn{2}{|c|}{$\begin{array}{c}\text { Average UV } \\
\text { Exposure } \\
\text { [ESH] }\end{array}$} & \multicolumn{6}{|c|}{ Max Adhesion Stress [psi] at Time [s] } \\
\hline & & & ID \#1 & ID \#2 & ID \#1 & ID \#2 & $3600 s$ & $7200 s$ & $14400 s$ & 28800s & 57600 s & $86400 s$ \\
\hline B-16 & B-17 & S0383-70 & 0 & 0 & 0 & 0 & 28.37 & 27.36 & 27.7 & 29.37 & 30.37 & 30.37 \\
\hline B-18 & B-19 & S0383-70 & 0 & 0 & 0 & 0 & 47.32 & 43.29 & 43.29 & 45.3 & 48.66 & 43.96 \\
\hline B-20 & B-21 & S0383-70 & 0 & 0 & 0 & 0 & 46.85 & 41.08 & 40.74 & 41.42 & 42.1 & 39.38 \\
\hline
\end{tabular}

AO Exposure

\begin{tabular}{|c|c|c|c|c|}
\hline \multirow[t]{3}{*}{ ID \#1 } & \multirow[t]{3}{*}{ ID \#2 } & \multirow[t]{3}{*}{ Compound } & \multirow{2}{*}{\multicolumn{2}{|c|}{$\begin{array}{l}\text { AO Fluence } \\
\left.\text { [atoms } / \mathrm{cm}^{2}\right]\end{array}$}} \\
\hline & & & & \\
\hline & & & ID \#1 & ID \#2 \\
\hline B-64 & B-85 & S0383-70 & $6.71 \mathrm{E}+21$ & $7.23 E+21$ \\
\hline B-68 & B-87 & S0383-70 & $7.59 \mathrm{E}+21$ & $7.64 \mathrm{E}+21$ \\
\hline B-84 & B-187 & S0383-70 & $5.29 \mathrm{E}+21$ & $5.36 \mathrm{E}+21$ \\
\hline B-130 & B-131 & S0383-70 & $1.50 E+21$ & $1.66 E+21$ \\
\hline B-181 & B-184 & S0383-70 & $3.06 \mathrm{E}+21$ & $3.05 E+21$ \\
\hline B-124 & B-125 & S0383-70 & $1.74 \mathrm{E}+21$ & $2.45 E+21$ \\
\hline B-126 & B-127 & S0383-70 & $2.51 \mathrm{E}+21$ & $1.75 E+21$ \\
\hline B-123 & B-129 & S0383-70 & $1.75 E+21$ & $2.30 E+21$ \\
\hline
\end{tabular}

$\begin{gathered}\text { Average UV } \\ \text { Exposure } \\ \text { [ESH] }\end{gathered}$
$\begin{array}{ccc}\text { ID \#1 } & \text { ID \#2 } & \mathbf{3 6 0 0 s} \\ 0 & 0 & 0 \\ 0 & 0 & 0 \\ 0 & 0 & 0 \\ 0 & 0 & 0.33 \\ 0 & 0 & 0 \\ 0 & 0 & 13.77 \\ 0 & 0 & 0.34 \\ 0 & 0 & 0.69\end{array}$

Max Adhesion Stress [psi] at Time [s]

AO + UV Exposure

\begin{tabular}{llccc} 
ID \#1 & ID \#2 & Compound & \multicolumn{2}{c}{ AO Fluence } \\
& & & \multicolumn{2}{c}{ [atoms/cm ${ }^{2}$ ] } \\
& & & ID \#1 & ID \#2 \\
B-65 & B-69 & S0383-70 & $6.02 E+21$ & $5.56 \mathrm{E}+21$ \\
B-66 & $\mathrm{B}-83$ & $\mathrm{~S} 0383-70$ & $6.02 \mathrm{E}+21$ & $6.04 \mathrm{E}+21$ \\
$\mathrm{~B}-65$ & $\mathrm{~B}-69$ & $\mathrm{~S} 0383-70$ & $6.02 \mathrm{E}+21$ & $5.56 \mathrm{E}+21$ \\
$\mathrm{~B}-66$ & $\mathrm{~B}-83$ & $\mathrm{~S} 0383-70$ & $6.02 \mathrm{E}+21$ & $6.04 \mathrm{E}+21$ \\
$\mathrm{~B}-65$ & $\mathrm{~B}-69$ & $\mathrm{~S} 0383-70$ & $6.02 \mathrm{E}+21$ & $5.56 \mathrm{E}+21$
\end{tabular}

\begin{tabular}{|c|c|c|}
\hline \multicolumn{2}{|c|}{$\begin{array}{c}\text { Average UV } \\
\text { Exposure } \\
\text { [ESH] }\end{array}$} & \multirow[b]{2}{*}{$3600 \mathrm{~s}$} \\
\hline ID \#1 & ID \#2 & \\
\hline 324.3 & 325.0 & - \\
\hline 558.9 & 552.6 & 0 \\
\hline 1181.7 & 1168.7 & 0 \\
\hline 1532.9 & 1531.4 & 0 \\
\hline 1533.7 & 1535.5 & 0 \\
\hline
\end{tabular}

Max Adhesion Stress [psi] at Time [s]

$\begin{array}{ccccc}7200 s & 14400 s & 28800 s & 57600 s & 86400 s \\ 0 & 0 & 0 & 0 & 0 \\ 0 & 0 & 0 & 0 & 0 \\ 0 & 0 & 0 & 0 & 0 \\ 0 & 0 & 0 & 0 & 0 \\ 0 & 0 & 0 & 0 & 0\end{array}$


2. Elastomer-to-Elastomer Adhesion Data for Parker Hannifin S0899-50

\section{As-Received}

$\begin{array}{lrr}\text { ID \#1 } & \text { ID \#2 } & \text { Compound } \\ & & \\ & & \\ \text { B-22 } & \text { B-23 } & \text { S08989-50 } \\ \text { B-24 } & \text { B-25 } & \text { S08989-50 } \\ \text { B-26 } & \text { B-27 } & \text { S08989-50 }\end{array}$

\begin{tabular}{|c|c|}
\hline \\
\hline \multicolumn{2}{|c|}{$\begin{array}{l}\text { AO Fluence } \\
\text { [atoms } / \mathrm{cm}^{2} \text { ] }\end{array}$} \\
\hline ID \#1 & ID \#2 \\
\hline 0 & 0 \\
\hline 0 & 0 \\
\hline 0 & 0 \\
\hline
\end{tabular}

$\begin{aligned} & \text { Average UV } \\ & \text { Exposure } \\ & \text { [ESH] }\end{aligned}$
$\begin{array}{ccc}\text { ID \#1 } & \text { ID \#2 } & \text { 3600s } \\ 0 & 0 & 75.86 \\ 0 & 0 & 98.5 \\ 0 & 0 & 79.71\end{array}$

Max Adhesion Stress [psi] at Time [s]

AO Exposure

\begin{tabular}{lllll} 
ID \#1 & ID \#2 & Compound & \multicolumn{2}{c}{ AO Fluence } \\
& & & \multicolumn{2}{c}{ [atoms/cm ${ }^{2}$ ] } \\
& & & ID \#1 & ID \#2 \\
$\mathrm{B}-88$ & $\mathrm{~B}-91$ & $\mathrm{~S} 08989-50$ & $7.26 \mathrm{E}+21$ & $7.45 \mathrm{E}+21$ \\
$\mathrm{~B}-90$ & $\mathrm{~B}-93$ & $\mathrm{~S} 08989-50$ & $5.17 \mathrm{E}+21$ & $5.19 \mathrm{E}+21$ \\
$\mathrm{~B}-144$ & $\mathrm{~B}-145$ & $\mathrm{~S} 08989-50$ & $1.60 \mathrm{E}+21$ & $1.57 \mathrm{E}+21$ \\
$\mathrm{~B}-197$ & $\mathrm{~B}-198$ & $\mathrm{~S} 08989-50$ & $2.96 \mathrm{E}+21$ & $2.91 \mathrm{E}+21$
\end{tabular}

$\begin{aligned} & \text { Average UV } \\ & \text { Exposure } \\ & \text { [ESH] }\end{aligned}$
$\begin{array}{ccc}\text { ID \#1 } & \text { ID \#2 } & \mathbf{3 6 0 0 s} \\ 0 & 0 & 7.36 \\ 0 & 0 & 6.70 \\ 0 & 0 & 11.94 \\ 0 & 0 & 10.52\end{array}$

Max Adhesion Stress [psi] at Time [s]

$\begin{array}{ccccc}\mathbf{7 2 0 0 s} & \mathbf{1 4 4 0 0 s} & \mathbf{2 8 8 0 0 s} & \mathbf{5 7 6 0 0 s} & \mathbf{8 6 4 0 0 s} \\ 6.40 & 8.64 & 8.96 & 10.24 & 9.6 \\ 7.02 & 2.56 & 9.58 & 8.94 & 9.89 \\ 11.62 & 10.97 & 12.59 & 13.23 & 12.91 \\ 10.52 & 10.84 & 11.16 & 12.12 & 12.12\end{array}$

AO + UV Exposure

$\begin{array}{lll}\text { ID \#1 } & \text { ID \#2 } & \text { Compound } \\ & & \\ & & \\ \text { B-70 } & \text { B-71 } & \text { S08989-50 } \\ \text { B-73 } & \text { B-75 } & \text { S08989-50 } \\ \text { B-70 } & \text { B-71 } & \text { S08989-50 } \\ \text { B-70 } & \text { B-71 } & \text { S08989-50 }\end{array}$

\begin{tabular}{cc}
\multicolumn{2}{c}{ AO Fluence } \\
\multicolumn{2}{c}{ [atoms/cm ${ }^{2}$ ] } \\
ID \#1 & ID \#2 \\
$6.22 \mathrm{E}+21$ & $6.50 \mathrm{E}+21$ \\
$5.41 \mathrm{E}+21$ & $5.23 \mathrm{E}+21$ \\
$6.22 \mathrm{E}+21$ & $6.50 \mathrm{E}+21$ \\
$6.22 \mathrm{E}+21$ & $6.50 \mathrm{E}+21$
\end{tabular}

\begin{tabular}{|c|c|c|}
\hline \multicolumn{2}{|c|}{$\begin{array}{c}\text { Average UV } \\
\text { Exposure } \\
\text { [ESH] }\end{array}$} & \multirow[b]{2}{*}{$3600 \mathrm{~s}$} \\
\hline ID \#1 & ID \#2 & \\
\hline 325.5 & 325.5 & - \\
\hline 558.3 & 553.4 & 0 \\
\hline 1174.1 & 1159.6 & 0 \\
\hline 1519.4 & 1519.0 & 0 \\
\hline
\end{tabular}

Max Adhesion Stress [psi] at Time [s]

$\begin{array}{ccccc}7200 s & 14400 s & 28800 s & 57600 s & 86400 s \\ 0 & 0 & 0 & 0 & 0 \\ 0 & 0 & 0 & 0 & 0 \\ 0 & 0 & 0 & 0 & 0 \\ 0 & 0 & 0 & 0 & 0\end{array}$


3. Elastomer-to-Elastomer Adhesion Data for Esterline XELA-SA-401

As-Received

$\begin{array}{lll}\text { ID \#1 } & \text { ID \#2 } & \text { Compound } \\ & & \\ \text { B-28 } & \text { B-29 } & \text { XELA-SA-401 } \\ \text { B-30 } & \text { B-30 } & \text { XELA-SA-401 } \\ \text { B-32 } & \text { B-33 } & \text { XELA-SA-401 }\end{array}$

\begin{tabular}{|c|c|}
\hline \multicolumn{2}{|c|}{ AO Fluence } \\
\hline [atc & $\left.\mathrm{cm}^{2}\right]$ \\
\hline ID \#1 & ID \#2 \\
\hline 0 & 0 \\
\hline 0 & 0 \\
\hline 0 & 0 \\
\hline
\end{tabular}

$\begin{aligned} & \text { Average UV } \\ & \text { Exposure } \\ & \text { [ESH] }\end{aligned}$
$\begin{array}{ccc}\text { ID \#1 } & \text { ID \#2 } & \mathbf{3 6 0 0 s} \\ 0 & 0 & 17.95 \\ 0 & 0 & 19.39 \\ 0 & 0 & 17.5\end{array}$

Max Adhesion Stress [psi] at Time [s]

AO Exposure

\begin{tabular}{lllll} 
ID \#1 & ID \#2 & Compound & \multicolumn{2}{c}{ AO Fluence } \\
& & & \multicolumn{2}{c}{ [atoms/cm ${ }^{2}$ ] } \\
& & & ID \#1 & ID \#2 \\
B-94 & B-96 & XELA-SA-401 & $7.01 \mathrm{E}+21$ & $7.39 E+21$ \\
B-153 & B-159 & XELA-SA-401 & $1.71 E+21$ & $1.51 E+21$ \\
B-208 & B-209 & XELA-SA-401 & $5.26 E+21$ & $5.37 E+21$ \\
B-206 & B-213 & XELA-SA-401 & $3.12 E+21$ & $3.09 E+21$
\end{tabular}

$\begin{aligned} & \text { Average UV } \\ & \text { Exposure } \\ & \text { [ESH] }\end{aligned}$
$\begin{array}{ccc}\text { ID \#1 } & \text { ID \#2 } & \mathbf{3 6 0 0 s} \\ 0 & 0 & 0 \\ 0 & 0 & 0 \\ 0 & 0 & 0 \\ 0 & 0 & 0\end{array}$

Max Adhesion Stress [psi] at Time [s]

$\begin{array}{ccccc}\mathbf{7 2 0 0 s} & \mathbf{1 4 4 0 0 s} & \mathbf{2 8 8 0 0 s} & \mathbf{5 7 6 0 0 s} & \mathbf{8 6 4 0 0 s} \\ 0 & 0 & 0 & 0 & 0 \\ 0 & 0 & 0 & 0 & 0 \\ 0 & 0 & 0 & 0 & 0 \\ 0 & 0.3 & 0.3 & 0.61 & 0.91\end{array}$

AO + UV Exposure

\begin{tabular}{lllcc} 
ID \#1 & ID \#2 & Compound & \multicolumn{2}{c}{ AO Fluence } \\
& & & \multicolumn{2}{c}{ [atoms/cm ${ }^{2}$ ] } \\
& & & ID \#1 & ID \#2 \\
B-76 & B-98 & XELA-SA-401 & $5.89 E+21$ & $5.77 E+21$ \\
B-80 & B-99 & XELA-SA-401 & $6.22 E+21$ & $6.03 E+21$ \\
B-76 & B-98 & XELA-SA-401 & $5.89 E+21$ & $5.77 E+21$ \\
B-76 & B-98 & XELA-SA-401 & $5.89 E+21$ & $5.77 E+21$
\end{tabular}

$\begin{aligned} & \text { Average UV } \\ & \text { Exposure } \\ & \text { [ESH] }\end{aligned}$
$\begin{array}{lcc}\text { ID \#1 } & \text { ID \#2 } & \mathbf{3 6 0 0 s} \\ 326.1 & 326.7 & - \\ 558.3 & 553.4 & 0 \\ 1178.3 & 1165.0 & 0 \\ 1537.0 & 1481.6 & 0\end{array}$

Max Adhesion Stress [psi] at Time [s]

$\begin{array}{ccccc}\mathbf{7 2 0 0 s} & \mathbf{1 4 4 0 0 s} & \mathbf{2 8 8 0 0 s} & \mathbf{5 7 6 0 0 s} & \mathbf{8 6 4 0 0 s} \\ 0 & 0 & 0 & 0 & 0 \\ 0 & 0 & 0 & 0 & 0 \\ 0 & 0 & 0 & 0 & 0 \\ 0 & 0 & 0 & 0 & 0\end{array}$




\section{VUV and NUV Components of Average UV Values}

\begin{tabular}{|c|c|c|c|c|c|}
\hline \multicolumn{3}{|c|}{$\begin{array}{l}\text { Parker Hannifin S0383-70 } \\
\text { B-65 }\end{array}$} & \multicolumn{3}{|c|}{ B-69 } \\
\hline $\begin{array}{l}\text { VUV } \\
\text { [ESH] }\end{array}$ & $\begin{array}{l}\text { NUV } \\
\text { [ESH] }\end{array}$ & $\begin{array}{l}\text { Avg. UV } \\
\text { [ESH] }\end{array}$ & $\begin{array}{l}\text { VUV } \\
\text { [ESH] }\end{array}$ & $\begin{array}{l}\text { NUV } \\
\text { [ESH] }\end{array}$ & $\begin{array}{l}\text { Avg. UV } \\
\text { [ESH] }\end{array}$ \\
\hline 267.0 & 381.5 & 324.3 & 275.0 & 375.0 & 325.0 \\
\hline 177.1 & 283.7 & 554.7 & 171.7 & 288.9 & 555.3 \\
\hline 223.9 & 313.9 & 823.6 & 275.9 & 280.0 & 833.3 \\
\hline 474.6 & 241.6 & 1181.7 & 404.6 & 266.2 & 1168.7 \\
\hline 405.3 & 298.8 & 1533.7 & 455.0 & 278.6 & 1535.5 \\
\hline & B-66 & & & B-83 & \\
\hline $\begin{array}{l}\text { VUV } \\
{[E S H]}\end{array}$ & $\begin{array}{l}\text { NUV } \\
{[\text { ESH] }}\end{array}$ & $\begin{array}{l}\text { Avg. UV } \\
\text { [ESH] }\end{array}$ & $\begin{array}{l}\text { VUV } \\
\text { [ESH] }\end{array}$ & $\begin{array}{l}\text { NUV } \\
\text { [ESH] }\end{array}$ & $\begin{array}{c}\text { Avg. UV } \\
\text { [ESH] }\end{array}$ \\
\hline 321.5 & 336.5 & 329.0 & 240.4 & 403.5 & 322.0 \\
\hline 140.3 & 319.4 & 558.9 & 195.1 & 266.2 & 552.6 \\
\hline 269.1 & 284.4 & 835.6 & 240.9 & 302.8 & 824.4 \\
\hline 432.8 & 257.7 & 1180.9 & 404.6 & 266.2 & 1159.8 \\
\hline 405.3 & 298.8 & 1532.9 & 471.2 & 271.9 & 1531.4 \\
\hline
\end{tabular}

\begin{tabular}{|c|c|c|c|c|c|}
\hline \multirow{2}{*}{\multicolumn{3}{|c|}{$\begin{array}{l}\text { Parker Hannifin S0899-50 } \\
\text { B-70 }\end{array}$}} & \multirow{2}{*}{\multicolumn{3}{|c|}{ B-71 }} \\
\hline & & & & & \\
\hline $\begin{array}{l}\text { VUV } \\
\text { [ESH] }\end{array}$ & $\begin{array}{l}\text { NUV } \\
\text { [ESH] }\end{array}$ & $\begin{array}{l}\text { Avg. UV } \\
\text { [ESH] }\end{array}$ & $\begin{array}{l}\text { VUV } \\
\text { [ESH] }\end{array}$ & $\begin{array}{l}\text { NUV } \\
\text { [ESH] }\end{array}$ & $\begin{array}{l}\text { Avg. UV } \\
\text { [ESH] }\end{array}$ \\
\hline 281.0 & 370.0 & 325.5 & 281.0 & 370.0 & 325.5 \\
\hline 181.4 & 279.3 & 555.9 & 167.7 & 293.8 & 556.3 \\
\hline 213.7 & 320.5 & 823.0 & 286.1 & 273.4 & 836.0 \\
\hline 451.8 & 250.4 & 1174.1 & 370.8 & 276.5 & 1159.6 \\
\hline \multirow[t]{2}{*}{382.7} & 308.0 & 1519.4 & 430.2 & 288.6 & 1519.0 \\
\hline & B-73 & & & B-75 & \\
\hline $\begin{array}{c}\text { VUV } \\
\text { [ESH] }\end{array}$ & $\begin{array}{c}\text { NUV } \\
\text { [ESH] }\end{array}$ & $\begin{array}{l}\text { Avg. UV } \\
\text { [ESH] }\end{array}$ & $\begin{array}{l}\text { VUV } \\
\text { [ESH] }\end{array}$ & $\begin{array}{c}\text { NUV } \\
\text { [ESH] }\end{array}$ & $\begin{array}{l}\text { Avg. UV } \\
\text { [ESH] }\end{array}$ \\
\hline 311.6 & 344.7 & 328.2 & 250.4 & 395.3 & 322.9 \\
\hline 147.3 & 312.9 & 558.3 & 188.4 & 272.8 & 553.4 \\
\hline 261.1 & 289.7 & 833.7 & 240.9 & 302.8 & 825.3 \\
\hline 420.7 & 261.4 & 1174.7 & 488.3 & 236.3 & 1187.6 \\
\hline 427.8 & 289.6 & 1533.4 & 355.6 & 319.0 & 1524.9 \\
\hline
\end{tabular}

\begin{tabular}{|c|c|c|c|c|c|}
\hline \multicolumn{6}{|c|}{ Esterline ELA-SA-401 } \\
\hline \multicolumn{3}{|c|}{ B-76 } & \multicolumn{3}{|c|}{ B-98 } \\
\hline $\begin{array}{l}\text { VUV } \\
\text { [ESH] }\end{array}$ & $\begin{array}{c}\text { NUV } \\
\text { [ESH] }\end{array}$ & $\begin{array}{c}\text { Avg. UV } \\
\text { [ESH] }\end{array}$ & $\begin{array}{l}\text { VUV } \\
\text { [ESH] }\end{array}$ & $\begin{array}{c}\text { NUV } \\
\text { [ESH] }\end{array}$ & $\begin{array}{c}\text { Avg. UV } \\
\text { [ESH] }\end{array}$ \\
\hline 287.0 & 365.1 & 326.1 & 294.9 & 358.5 & 326.7 \\
\hline 163.7 & 296.7 & 556.3 & 158.3 & 301.9 & 556.8 \\
\hline 269.1 & 284.4 & 833.0 & 296.3 & 266.7 & 838.3 \\
\hline 432.8 & 257.7 & 1178.3 & 350.5 & 282.6 & 1154.9 \\
\hline 427.8 & 289.6 & 1537.0 & 414.9 & 294.8 & 1509.7 \\
\hline & B-80 & & & B-99 & \\
\hline $\begin{array}{c}\text { VUV } \\
\text { [ESH] }\end{array}$ & $\begin{array}{c}\text { NUV } \\
\text { [ESH] }\end{array}$ & $\begin{array}{c}\text { Avg. UV } \\
\text { [ESH] }\end{array}$ & $\begin{array}{c}\text { VUV } \\
\text { [ESH] }\end{array}$ & $\begin{array}{c}\text { NUV } \\
\text { [ESH] }\end{array}$ & $\begin{array}{c}\text { Avg. UV } \\
\text { [ESH] }\end{array}$ \\
\hline 311.6 & 344.7 & 328.2 & 250.4 & 395.3 & 322.9 \\
\hline 147.3 & 312.9 & 558.3 & 188.4 & 272.8 & 553.4 \\
\hline 255.0 & 293.6 & 832.6 & 270.6 & 283.4 & 830.5 \\
\hline 440.9 & 254.6 & 1180.3 & 453.8 & 249.6 & 1182.2 \\
\hline 395.6 & 302.7 & 1529.5 & & & \\
\hline
\end{tabular}




\section{Appendix D Leakage Flow Data}

\section{Leakage Flow Data for Parker Hannifin S0383-70}

As-received

\begin{tabular}{|c|c|c|c|c|c|c|c|c|c|}
\hline ID & Compound & $\begin{array}{l}\text { AO Fluence } \\
\text { [atoms } / \mathrm{cm}^{2} \text { ] }\end{array}$ & $\begin{array}{c}\text { Average } \\
\text { UV } \\
\text { Exposure } \\
\text { [ESH] }\end{array}$ & $\begin{array}{l}\text { Leakage } \\
\text { Rate } \\
\text { [lbm/day] }\end{array}$ & $\begin{array}{c}\text { Upper } \\
\text { Error } \\
\text { Limit } \\
\text { [lbm/day] }\end{array}$ & $\begin{array}{l}\text { Lower } \\
\text { Error } \\
\text { Limit } \\
\text { [lbm/day] }\end{array}$ & $\begin{array}{l}\text { Leakage } \\
\text { Rate } \\
\text { (kg/day) }\end{array}$ & $\begin{array}{c}\text { Upper } \\
\text { Error } \\
\text { Limit } \\
\text { (kg/day) }\end{array}$ & $\begin{array}{l}\text { Lower } \\
\text { Error } \\
\text { Limit } \\
\text { (kg/day) }\end{array}$ \\
\hline $309-10$ & S0383-70 & $0.00 \mathrm{E}+00$ & 0.0 & 8.32E-07 & 1.23 & 4.3 & $3.77 \mathrm{E}-07$ & $5.58 \mathrm{E}-07$ & $1.99 \mathrm{E}-07$ \\
\hline $309-10$ & S0383-70 & $0.00 \mathrm{E}+00$ & 0.0 & $1.34 \mathrm{E}-06$ & 6.07E-06 & $1.00 \mathrm{E}-20$ & $6.08 \mathrm{E}-07$ & $2.75 \mathrm{E}-06$ & 4.54E-21 \\
\hline $309-10$ & S0383-70 & $0.00 \mathrm{E}+00$ & 0.0 & 1.48E-06 & 6.21E-06 & $1.00 \mathrm{E}-20$ & $6.72 \mathrm{E}-07$ & 2.82E-06 & 4.54E-21 \\
\hline $309-11$ & S0383-70 & $0.00 \mathrm{E}+00$ & 0.0 & $1.22 \mathrm{E}-06$ & 5.95E-06 & $1.00 \mathrm{E}-20$ & $5.52 \mathrm{E}-07$ & $2.70 \mathrm{E}-06$ & $4.54 \mathrm{E}-21$ \\
\hline $309-11$ & S0383-70 & $0.00 \mathrm{E}+00$ & 0.0 & $1.87 \mathrm{E}-06$ & $6.58 \mathrm{E}-06$ & $1.00 \mathrm{E}-20$ & $8.46 \mathrm{E}-07$ & $2.98 \mathrm{E}-06$ & $4.54 \mathrm{E}-21$ \\
\hline
\end{tabular}

AO Exposure

\begin{tabular}{|c|c|c|c|c|c|c|c|c|c|}
\hline ID & Compound & $\begin{array}{l}\text { AO Fluence } \\
\text { [atoms } / \mathrm{cm}^{2} \text { ] }\end{array}$ & $\begin{array}{c}\text { Average } \\
\text { UV } \\
\text { Exposure } \\
\text { [ESH] }\end{array}$ & $\begin{array}{l}\text { Leakage } \\
\text { Rate } \\
\text { [lbm/day] }\end{array}$ & $\begin{array}{c}\text { Upper } \\
\text { Error } \\
\text { Limit } \\
\text { [lbm/day] }\end{array}$ & $\begin{array}{l}\text { Lower } \\
\text { Error } \\
\text { Limit } \\
\text { [lbm/day] }\end{array}$ & $\begin{array}{l}\text { Leakage } \\
\text { Rate } \\
\text { (kg/day) }\end{array}$ & $\begin{array}{c}\text { Upper } \\
\text { Error } \\
\text { Limit } \\
\text { (kg/day) }\end{array}$ & $\begin{array}{l}\text { Lower } \\
\text { Error } \\
\text { Limit } \\
\text { (kg/day) }\end{array}$ \\
\hline 101 & S0383-70 & $2.35 \mathrm{E}+21$ & 0.0 & $2.42 \mathrm{E}-06$ & 7.13E-06 & $1.00 \mathrm{E}-20$ & -06 & 3.23 & $E-21$ \\
\hline 101 & S0383-70 & $2.35 \mathrm{E}+21$ & 0.0 & $3.48 \mathrm{E}-06$ & $8.17 \mathrm{E}-06$ & 1.00E-20 & $1.58 \mathrm{E}-06$ & $3.71 \mathrm{E}-06$ & $4.54 \mathrm{E}-21$ \\
\hline 163 & S0383-70 & $3.95 E+21$ & 0.0 & $2.42 \mathrm{E}-06$ & 7.13E-06 & $1.00 \mathrm{E}-20$ & 1.10E-06 & $3.23 E-06$ & $4.54 \mathrm{E}-21$ \\
\hline 163 & S0383-70 & $3.95 \mathrm{E}+21$ & 0.0 & 4.66E-06 & $9.41 \mathrm{E}-06$ & $1.00 \mathrm{E}-20$ & $2.12 \mathrm{E}-06$ & 4.27E-06 & $4.54 \mathrm{E}-21$ \\
\hline 43 & S0383-70 & $6.04 \mathrm{E}+21$ & 0.0 & $2.58 \mathrm{E}-06$ & 7.32E-06 & 1.00E-20 & 1.17E-06 & 3.32E-06 & $4.54 \mathrm{E}-21$ \\
\hline 43 & S0383-70 & $6.04 \mathrm{E}+21$ & 0.0 & $3.58 \mathrm{E}-06$ & 8.31E-06 & $1.00 \mathrm{E}-20$ & $1.63 \mathrm{E}-06$ & $3.77 \mathrm{E}-06$ & 4.54E-21 \\
\hline 44 & S0383-70 & $4.93 E+21$ & 0.0 & 4.15E-06 & 8.97E-06 & $1.00 \mathrm{E}-20$ & $1.88 \mathrm{E}-06$ & 4.07E-06 & 4.54E-21 \\
\hline 44 & S0383-70 & $4.93 E+21$ & 0.0 & $5.04 \mathrm{E}-06$ & $9.81 \mathrm{E}-06$ & $2.60 \mathrm{E}-07$ & $2.28 \mathrm{E}-06$ & 4.45E-06 & 1.18E-07 \\
\hline 49 & S0383-70 & $6.71 \mathrm{E}+21$ & 0.0 & 2.15E-06 & $6.85 \mathrm{E}-06$ & $1.00 \mathrm{E}-20$ & $9.76 \mathrm{E}-07$ & 3.11E-06 & $4.54 \mathrm{E}-21$ \\
\hline 49 & S0383-70 & $6.71 \mathrm{E}+21$ & 0.0 & 4.92E-06 & $9.65 \mathrm{E}-06$ & 1.81E-07 & 2.23E-06 & 4.38E-06 & $8.21 \mathrm{E}$ \\
\hline
\end{tabular}

AO + UV Exposure

\begin{tabular}{|c|c|c|c|c|c|c|c|c|c|}
\hline ID & Compound & $\begin{array}{l}\text { AO Fluence } \\
\text { [atoms } / \mathrm{cm}^{2} \text { ] }\end{array}$ & $\begin{array}{c}\text { Average } \\
\text { UV } \\
\text { Exposure } \\
\text { [ESH] }\end{array}$ & $\begin{array}{l}\text { Leakage } \\
\text { Rate } \\
\text { [lbm/day] }\end{array}$ & $\begin{array}{c}\text { Upper } \\
\text { Error } \\
\text { Limit } \\
\text { [lbm/day] }\end{array}$ & $\begin{array}{l}\text { Lower } \\
\text { Error } \\
\text { Limit } \\
\text { [lbm/day] }\end{array}$ & $\begin{array}{l}\text { Leakage } \\
\text { Rate } \\
\text { (kg/day) }\end{array}$ & $\begin{array}{c}\text { Upper } \\
\text { Error } \\
\text { Limit } \\
\text { (kg/day) }\end{array}$ & $\begin{array}{c}\text { Lower } \\
\text { Error } \\
\text { Limit } \\
\text { (kg/day) }\end{array}$ \\
\hline 64 & S0383-70 & $5.11 \mathrm{E}+21$ & 324.3 & $6.53 \mathrm{E}$ & 05 & $1.77 \mathrm{E}$ & 06 & 5.13E-06 & $0.005-U 1$ \\
\hline 164 & S0383-70 & $5.11 \mathrm{E}+21$ & 324.3 & 1.71E-05 & 2.18E-05 & $1.23 \mathrm{E}-05$ & & 9.89E-06 & 5.58E-06 \\
\hline 164 & S0383-70 & $5.11 \mathrm{E}+21$ & 554.4 & 1.76E-05 & 2.22E-05 & 1.30E-05 & $9 \mathrm{E}-06$ & $1.01 \mathrm{E}-05$ & $5.90 \mathrm{E}-06$ \\
\hline 164 & S0383-70 & $5.11 \mathrm{E}+21$ & 554.4 & $1.68 \mathrm{E}-05$ & $2.15 \mathrm{E}-05$ & 1.21E-05 & 7.61 & $9.75 \mathrm{E}-06$ & $5.49 \mathrm{E}-06$ \\
\hline 164 & S0383-70 & $5.11 \mathrm{E}+21$ & 823.3 & 3.29E-05 & 3.75E-05 & 2.82E-05 & & $1.70 \mathrm{E}-05$ & $1.28 \mathrm{E}-05$ \\
\hline 164 & S0383-70 & $5.11 \mathrm{E}+21$ & 823.3 & 2.75 & $3.22 \mathrm{E}-05$ & $2.28 \mathrm{E}-05$ & & $1.46 \mathrm{E}-05$ & 1.03E-05 \\
\hline 164 & S0383-70 & $5.11 \mathrm{E}+21$ & 1181.4 & $3.6 \mathrm{~s}$ & $E-05$ & $3.23 \mathrm{E}-05$ & & E-05 & 1.47E-05 \\
\hline 164 & S0383-70 & $5.11 \mathrm{E}+21$ & 1181.4 & & $=-05$ & 3.30E-05 & & $E-05$ & $1.50 \mathrm{E}-05$ \\
\hline 64 & $3-70$ & 5.1 & 1548.2 & 4.4 & $E-05$ & $3.94 \mathrm{E}-05$ & & $E-05$ & E-05 \\
\hline 164 & $\mathrm{~S} 03$ & $5.11 \mathrm{E}+21$ & 1548.2 & & $=-05$ & 4.41E-05 & & $E-05$ & $2.00 \mathrm{E}-05$ \\
\hline 165 & S0383-70 & $5.36 \mathrm{E}+21$ & 322.9 & & 1.87E-05 & $9.24 \mathrm{E}-06$ & & $8.48 \mathrm{E}-06$ & 4.19E-06 \\
\hline 165 & S0383-70 & $5.36 \mathrm{E}+21$ & 322.9 & & $2.12 \mathrm{E}-05$ & $1.17 \mathrm{E}-05$ & & $9.62 \mathrm{E}-06$ & $5.31 \mathrm{E}-06$ \\
\hline 165 & S0383-70 & $5.36 \mathrm{E}+21$ & 553.0 & 5.57E-05 & $6.03 \mathrm{E}-05$ & 5.11E-05 & $2.53 E-05$ & $2.74 \mathrm{E}-05$ & 2.32E-05 \\
\hline 165 & S0383-70 & $5.36 \mathrm{E}+21$ & 553.0 & $5.30 \mathrm{E}-05$ & $5.78 \mathrm{E}-05$ & 4.83E-05 & $2.41 \mathrm{E}-05$ & $2.62 \mathrm{E}-05$ & 2.19E-05 \\
\hline 165 & S0383-70 & $5.36 \mathrm{E}+21$ & 824.8 & 9.56E-05 & $1.00 \mathrm{E}-04$ & 9.09E-05 & 4.34E-05 & 4.54E-05 & 4.12E-05 \\
\hline 165 & S0383-70 & $5.36 \mathrm{E}+21$ & 824.8 & 8.28E-05 & 8.75E-05 & 7.81E-05 & & 3.97E-05 & $3.54 \mathrm{E}-05$ \\
\hline 165 & S0383-70 & $5.36 \mathrm{E}+21$ & 1182.9 & 1.57 & 1.64E-04 & $1.50 \mathrm{E}-04$ & & 7.44E-05 & $6.80 \mathrm{E}-05$ \\
\hline 65 & S0383-70 & $5.36 \mathrm{E}+21$ & 1182.9 & & 1.32E-04 & $1.22 \mathrm{E}-04$ & & 5.99E-05 & 5.53E-05 \\
\hline 165 & & $5.36 \mathrm{E}+21$ & & & 2.27E-04 & 2.09E-04 & & E-04 & $9.48 \mathrm{E}-0$ \\
\hline 65 & S0383-70 & $5.36 \mathrm{E}+21$ & 1541.6 & $2.16 \mathrm{E}-04$ & $2.25 \mathrm{E}-04$ & 2.07E-04 & $9.80 \mathrm{E}-05$ & $1.02 \mathrm{E}-04$ & $9.39 \mathrm{E}-05$ \\
\hline
\end{tabular}




\section{Leakage Flow Data for Parker Hannifin S899-50}

\begin{tabular}{|c|c|c|c|c|c|c|c|c|c|}
\hline \multicolumn{3}{|c|}{ As-received } & \multirow[b]{2}{*}{$\begin{array}{c}\text { Average } \\
\text { UV } \\
\text { Exposure } \\
\text { [ESH] }\end{array}$} & \multirow[b]{2}{*}{$\begin{array}{c}\text { Leakage } \\
\text { Rate } \\
\text { [lbm/day] }\end{array}$} & \multirow[b]{2}{*}{$\begin{array}{c}\text { Upper } \\
\text { Error } \\
\text { Limit } \\
\text { [lbm/day] }\end{array}$} & \multirow[b]{2}{*}{$\begin{array}{l}\text { Lower } \\
\text { Error } \\
\text { Limit } \\
\text { [lbm/day] }\end{array}$} & \multirow[b]{2}{*}{$\begin{array}{l}\text { Leakage } \\
\text { Rate } \\
\text { (kg/day) }\end{array}$} & \multirow[b]{2}{*}{$\begin{array}{c}\text { Upper } \\
\text { Error } \\
\text { Limit } \\
\text { (kg/day) }\end{array}$} & \multirow[b]{2}{*}{$\begin{array}{c}\text { Lower } \\
\text { Error } \\
\text { Limit } \\
\text { (kg/day) }\end{array}$} \\
\hline ID & Compound & $\begin{array}{l}\text { AO Fluence } \\
\text { [atoms } / \mathrm{cm}^{2} \text { ] }\end{array}$ & & & & & & & \\
\hline $309-12$ & S0899-50 & $0.00 \mathrm{E}+00$ & 0.0 & $6.84 \mathrm{E}-07$ & 5.39E-06 & 1.00E-20 & $3.10 \mathrm{E}-07$ & $2.44 \mathrm{E}-06$ & $4.54 \mathrm{E}-21$ \\
\hline $309-12$ & S0899-50 & $0.00 \mathrm{E}+00$ & 0.0 & 2.26E-06 & 2.65E-06 & 1.87E-06 & 1.03E-06 & $1.20 \mathrm{E}-06$ & 8.48E-07 \\
\hline $309-12$ & S0899-50 & $0.00 \mathrm{E}+00$ & 0.0 & 3.79E-06 & 8.53E-06 & $1.00 \mathrm{E}-20$ & $1.72 \mathrm{E}-06$ & 3.87E-06 & $4.54 \mathrm{E}-21$ \\
\hline $309-13$ & S0899-50 & $0.00 \mathrm{E}+00$ & 0.0 & $2.77 \mathrm{E}-06$ & $7.50 \mathrm{E}-06$ & 1.00E-20 & $1.25 \mathrm{E}-06$ & $3.40 \mathrm{E}-06$ & $4.54 \mathrm{E}-21$ \\
\hline $309-13$ & S0899-50 & $0.00 \mathrm{E}+00$ & 0.0 & $2.78 \mathrm{E}-06$ & 7.50E-06 & $1.00 \mathrm{E}-20$ & $1.26 \mathrm{E}-06$ & $3.40 \mathrm{E}-06$ & $4.54 \mathrm{E}-21$ \\
\hline
\end{tabular}

AO Exposure

\begin{tabular}{|c|c|c|c|c|c|c|c|c|c|}
\hline ID & Compound & $\begin{array}{l}\text { AO Fluence } \\
\text { [atoms } / \mathrm{cm}^{2} \text { ] }\end{array}$ & $\begin{array}{c}\text { Average } \\
\text { UV } \\
\text { Exposure } \\
\text { [ESH] }\end{array}$ & $\begin{array}{l}\text { Leakage } \\
\text { Rate } \\
\text { [lbm/day] }\end{array}$ & $\begin{array}{c}\text { Upper } \\
\text { Error } \\
\text { Limit } \\
\text { [lbm/day] }\end{array}$ & $\begin{array}{l}\text { Lower } \\
\text { Error } \\
\text { Limit } \\
\text { [lbm/day] }\end{array}$ & $\begin{array}{c}\text { Leakage } \\
\text { Rate } \\
\text { (kg/day) }\end{array}$ & $\begin{array}{l}\text { Upper } \\
\text { Error } \\
\text { Limit } \\
\text { (kg/day) }\end{array}$ & $\begin{array}{l}\text { Lower } \\
\text { Error } \\
\text { Limit } \\
\text { (kg/day) }\end{array}$ \\
\hline 108 & S0899-50 & $2.47 \mathrm{E}+21$ & 0.0 & $5.29 \mathrm{E}-06$ & 9.95E-06 & 6.31E-07 & $2.40 \mathrm{E}-06$ & 4.51E-06 & 2.86E-07 \\
\hline 108 & S0899-50 & $2.47 E+21$ & 0.0 & 8.54E-06 & 1.32E-05 & 3.86E-06 & 3.87E-06 & 5.99E-06 & 1.75E-06 \\
\hline 168 & S0899-50 & $4.66 \mathrm{E}+21$ & 0.0 & 2.98E-06 & 7.70E-06 & 1.00E-20 & 1.35E-06 & $3.49 \mathrm{E}-06$ & $4.54 \mathrm{E}-21$ \\
\hline 168 & S0899-50 & $4.66 \mathrm{E}+21$ & 0.0 & 8.04E-06 & 1.27E-05 & 3.33E-06 & $3.64 \mathrm{E}-06$ & 5.76E-06 & $1.51 \mathrm{E}-06$ \\
\hline 172 & S0899-50 & $3.47 \mathrm{E}+21$ & 0.0 & 4.84E-06 & 9.57E-06 & $1.00 \mathrm{E}-07$ & 2.19E-06 & 4.34E-06 & $4.54 \mathrm{E}-08$ \\
\hline 172 & S0899-50 & $3.47 \mathrm{E}+21$ & 0.0 & 8.76E-06 & 1.35E-05 & 4.04E-06 & 3.97E-06 & $6.12 \mathrm{E}-06$ & 1.83E-06 \\
\hline 45 & S0899-50 & $7.23 E+21$ & 0.0 & 6.39E-06 & 1.11E-05 & 1.65E-06 & $2.90 \mathrm{E}-06$ & $5.03 \mathrm{E}-06$ & $7.48 \mathrm{E}-07$ \\
\hline 45 & S0899-50 & $7.23 E+21$ & 0.0 & 6.41E-06 & 1.11E-05 & 1.69E-06 & 2.91E-06 & 5.03E-06 & 7.67E-07 \\
\hline 46 & S0899-50 & $5.23 E+21$ & 0.0 & 5.49E-06 & 1.02E-05 & 7.99E-07 & 2.49E-06 & 4.63E-06 & 3.62E-07 \\
\hline 46 & S0899-50 & $5.23 E+21$ & 0.0 & 7.85E-06 & 1.26E-05 & 3.12E-06 & 3.56E-06 & 5.72E-06 & 1.42E-06 \\
\hline
\end{tabular}

AO + UV Exposure

\begin{tabular}{|c|c|c|c|c|c|c|c|c|c|}
\hline ID & Compound & AO Fluence & $\begin{array}{c}\text { Average } \\
\text { UV } \\
\text { Exposure }\end{array}$ & $\begin{array}{l}\text { Leakage } \\
\text { Rate }\end{array}$ & $\begin{array}{l}\text { Upper } \\
\text { Error } \\
\text { Limit }\end{array}$ & $\begin{array}{l}\text { Lower } \\
\text { Error } \\
\text { Limit }\end{array}$ & $\begin{array}{c}\text { Leakage } \\
\text { Rate }\end{array}$ & $\begin{array}{l}\text { Upper } \\
\text { Error } \\
\text { Limit }\end{array}$ & $\begin{array}{l}\text { Lower } \\
\text { Error } \\
\text { Limit }\end{array}$ \\
\hline & & [atoms $/ \mathrm{cm}^{2}$ ] & [ESH] & [lbm/day] & [lbm/day] & [lbm/day] & (kg/day) & (kg/day) & (kg/day) \\
\hline 60 & S0899-50 & $7.26 \mathrm{E}+21$ & 328.2 & $1.61 \mathrm{E}-04$ & $1.68 \mathrm{E}-04$ & $1.55 \mathrm{E}-04$ & 7.31E-05 & 7.62E-05 & 7.03E-05 \\
\hline 60 & S0899-50 & $7.26 \mathrm{E}+21$ & 328.2 & 1.67E-04 & 1.74E-04 & $1.60 \mathrm{E}-04$ & $7.58 \mathrm{E}-05$ & 7.89E-05 & 7.26E-05 \\
\hline 60 & S0899-50 & $7.26 \mathrm{E}+21$ & 558.7 & $4.27 \mathrm{E}-04$ & 4.45E-04 & 4.08E-04 & & 2.02E-04 & 1.85E-04 \\
\hline 60 & S0899-50 & $7.26 \mathrm{E}+21$ & & $4.06 \mathrm{E}-04$ & 4.23E-04 & & & 1.92E-04 & 1.76E-04 \\
\hline 60 & S0899-50 & +21 & 83 & $8.02 \mathrm{E}$ & 8.37E-04 & & & -04 & $3.48 \mathrm{E}-04$ \\
\hline 60 & S08s & +21 & 830.6 & 7.11E-04 & 7.42E-04 & 6.8 & & -04 & 3.08E-04 \\
\hline 60 & -50 & -21 & 1154.2 & & 03 & & & & $E-04$ \\
\hline 60 & S0899-50 & 7.26 & 1154.2 & 1.00 & $1.04 \mathrm{E}-03$ & 9.5 & 4.5 & $4.72 \mathrm{E}-04$ & 4.35E-04 \\
\hline 60 & S0899-50 & $7.26 \mathrm{E}+21$ & 1499.6 & $1.41 \mathrm{E}-03$ & 1.47E-03 & 1.35 & 6.38 & $6.67 \mathrm{E}-04$ & $6.12 \mathrm{E}-04$ \\
\hline 60 & S0899-50 & $7.26 \mathrm{E}+21$ & 1499.6 & 1.36 & $1.41 \mathrm{E}-03$ & 1.30 & -04 & $6.40 \mathrm{E}-04$ & $5.90 \mathrm{E}-04$ \\
\hline 169 & S0899-50 & $5.49 \mathrm{E}+21$ & 322.9 & $3.25 \mathrm{E}-05$ & $3.73 \mathrm{E}-05$ & $2.77 \mathrm{E}-05$ & 1.47E-05 & 1.69E-05 & 1.26E-05 \\
\hline 169 & S0899-50 & $5.49 \mathrm{E}+21$ & 322.9 & 3.07E-05 & 3.55E-05 & 2.59E-05 & 1.39E-05 & 1.61E-05 & 1.17E-05 \\
\hline 169 & S0899-50 & $5.49 \mathrm{E}+21$ & 553.0 & $1.81 \mathrm{E}-04$ & $1.89 \mathrm{E}-04$ & 1.73E-04 & 8.23E-05 & 8.57E-05 & 7.85E-05 \\
\hline 169 & S0899-50 & $5.49 \mathrm{E}+21$ & 553.0 & $2.20 \mathrm{E}-04$ & 2.29E-04 & $2.10 \mathrm{E}-04$ & 9.96E-05 & $1.04 \mathrm{E}-04$ & $9.53 \mathrm{E}-05$ \\
\hline 169 & S0899-50 & $5.49 \mathrm{E}+21$ & 832.7 & $6.39 \mathrm{E}-04$ & 6.67E-04 & 6.11E-04 & $2.90 \mathrm{E}-04$ & 3.03E-04 & 2.77E-04 \\
\hline 169 & S0899-50 & $5.49 \mathrm{E}+21$ & 832.7 & $5.22 \mathrm{E}-04$ & $5.45 \mathrm{E}-04$ & 4.99E-04 & & $2.47 \mathrm{E}-04$ & $2.26 \mathrm{E}-04$ \\
\hline 169 & S0899-50 & $5.49 E+21$ & 1183.8 & & 1.32E-03 & & & 5.99E-04 & 5.49E-04 \\
\hline 169 & S0899-50 & & 1183.8 & & $1.28 \mathrm{E}-03$ & & & $E-04$ & 5.31E-04 \\
\hline $16 s$ & S0899-50 & & & & $1.68 \mathrm{E}-03$ & 1.5 & & $7.62 \mathrm{E}-04$ & $6.94 \mathrm{E}-04$ \\
\hline 169 & S0899-50 & $5.49 \mathrm{E}+21$ & 1529.1 & $1.99 \mathrm{E}-03$ & 2.10E-03 & $1.88 \mathrm{E}-03$ & $9.04 \mathrm{E}-04$ & $9.53 E-04$ & $8.53 \mathrm{E}-0$ \\
\hline
\end{tabular}




\section{Leakage Flow Data for Esterline ELA-SA-401}

\begin{tabular}{|c|c|c|c|c|c|c|c|c|c|}
\hline \multicolumn{3}{|c|}{ As-received } & \multirow[b]{2}{*}{$\begin{array}{c}\text { Average } \\
\text { UV } \\
\text { Exposure } \\
\text { [ESH] }\end{array}$} & \multirow[b]{2}{*}{$\begin{array}{l}\text { Leakage } \\
\text { Rate } \\
\text { [lbm/day] }\end{array}$} & \multirow[b]{2}{*}{$\begin{array}{c}\text { Upper } \\
\text { Error } \\
\text { Limit } \\
\text { [lbm/day] }\end{array}$} & \multirow[b]{2}{*}{$\begin{array}{l}\text { Lower } \\
\text { Error } \\
\text { Limit } \\
\text { [lbm/day] }\end{array}$} & \multirow[b]{2}{*}{$\begin{array}{c}\text { Leakage } \\
\text { Rate } \\
\text { (kg/day) }\end{array}$} & \multirow[b]{2}{*}{$\begin{array}{c}\text { Upper } \\
\text { Error } \\
\text { Limit } \\
\text { (kg/day) }\end{array}$} & \multirow[b]{2}{*}{$\begin{array}{l}\text { Lower } \\
\text { Error } \\
\text { Limit } \\
\text { (kg/day) }\end{array}$} \\
\hline ID & Compound & $\begin{array}{l}\text { AO Fluence } \\
\text { [atoms } / \mathrm{cm}^{2} \text { ] }\end{array}$ & & & & & & & \\
\hline 309 & & & 0. & & & & & & \\
\hline $309-14$ & $\mathrm{EL}$ & 0.0 & 0.0 & 1.91 & 06 & 1.0 & 8.6 & 3.0 & -21 \\
\hline $309-14$ & ELA-SA-401 & $0.00 \mathrm{E}+00$ & 0.0 & 4.11E-06 & 8.83E-06 & $1.00 \mathrm{E}-20$ & $1.86 \mathrm{E}-06$ & 4.01E-06 & 4.54E-21 \\
\hline $309-14$ & ELA-SA-401 & $0.00 \mathrm{E}+00$ & 0.0 & $4.88 \mathrm{E}-06$ & $9.59 \mathrm{E}-06$ & $1.64 \mathrm{E}-07$ & $2.21 \mathrm{E}-06$ & 4.35E-06 & $7.44 \mathrm{E}-08$ \\
\hline $309-15$ & ELA-SA-401 & $0.00 \mathrm{E}+00$ & 0.0 & $2.30 \mathrm{E}-06$ & 7.01E-06 & $1.00 \mathrm{E}-20$ & $1.04 \mathrm{E}-06$ & $3.18 \mathrm{E}-06$ & $4.54 \mathrm{E}-21$ \\
\hline
\end{tabular}

AO Exposure

\begin{tabular}{|c|c|c|c|c|c|c|c|c|c|}
\hline ID & Compound & $\begin{array}{l}\text { AO Fluence } \\
\text { [atoms } / \mathrm{cm}^{2} \text { ] }\end{array}$ & $\begin{array}{c}\text { Average } \\
\text { UV } \\
\text { Exposure } \\
\text { [ESH] }\end{array}$ & $\begin{array}{l}\text { Leakage } \\
\text { Rate } \\
\text { [lbm/day] }\end{array}$ & $\begin{array}{c}\text { Upper } \\
\text { Error } \\
\text { Limit } \\
\text { [lbm/day] }\end{array}$ & $\begin{array}{l}\text { Lower } \\
\text { Error } \\
\text { Limit } \\
\text { [lbm/day] }\end{array}$ & $\begin{array}{c}\text { Leakage } \\
\text { Rate } \\
\text { (kg/day) }\end{array}$ & $\begin{array}{l}\text { Upper } \\
\text { Error } \\
\text { Limit } \\
\text { (kg/day) }\end{array}$ & $\begin{array}{l}\text { Lower } \\
\text { Error } \\
\text { Limit } \\
\text { (kg/day) }\end{array}$ \\
\hline 115 & ELA-S & $2.14 \mathrm{E}+21$ & 0.0 & 3.33E-06 & $.00 \mathrm{E}-06$ & 1.00 & $1.51 \mathrm{E}-06$ & $3.63 \mathrm{E}-06$ & $4.54 \mathrm{E}-21$ \\
\hline 115 & ELA-S & 2.1 & 0.0 & $3.98 \mathrm{E}-06$ & $8.64 \mathrm{E}-06$ & 1.00 & 1.81 & $3.92 \mathrm{E}-06$ & $4.54 \mathrm{E}-21$ \\
\hline 173 & ELA-SA-401 & $2.84 \mathrm{E}+21$ & 0.0 & 1.96E-06 & 6.71E-06 & $1.00 \mathrm{E}-20$ & 8.88E-07 & 3.0 & $4.54 \mathrm{E}-21$ \\
\hline 173 & ELA-SA-401 & $2.84 \mathrm{E}+21$ & 0.0 & 6.36E-06 & 1.11E-05 & 1.60E-06 & 2.89E-06 & 5.03E-06 & 7.26E-07 \\
\hline 174 & ELA-SA-401 & $4.36 \mathrm{E}+21$ & 0.0 & $2.39 \mathrm{E}-06$ & 7.13E-06 & $1.00 \mathrm{E}-20$ & $1.08 \mathrm{E}-06$ & $3.23 \mathrm{E}-06$ & $4.54 \mathrm{E}-21$ \\
\hline 174 & ELA-SA-401 & $4.36 \mathrm{E}+21$ & 0.0 & 2.61E-06 & 7.33E-06 & $1.00 \mathrm{E}-20$ & $1.18 \mathrm{E}-06$ & $3.32 \mathrm{E}-06$ & $4.54 \mathrm{E}-21$ \\
\hline 47 & ELA-SA-401 & $7.01 \mathrm{E}+21$ & 0.0 & 3.71E-06 & 8.44E-06 & $1.00 \mathrm{E}-20$ & $1.68 \mathrm{E}-06$ & 3.83E-06 & $4.54 \mathrm{E}-21$ \\
\hline 47 & ELA-SA-401 & $7.01 \mathrm{E}+21$ & 0.0 & 8.12E-06 & $1.28 \mathrm{E}-05$ & $3.40 \mathrm{E}-06$ & $3.68 \mathrm{E}-06$ & 5.81E-06 & $1.54 \mathrm{E}-06$ \\
\hline 48 & ELA-SA-401 & $6.22 \mathrm{E}+21$ & 0.0 & 3.99E-06 & $8.72 \mathrm{E}-06$ & $1.00 \mathrm{E}-20$ & 1.81E-06 & 3.96E-06 & $4.54 \mathrm{E}-21$ \\
\hline 48 & ELA-SA-401 & $6.22 \mathrm{E}+21$ & 0.0 & 5.81E-06 & $1.05 \mathrm{E}-05$ & 1.11E-06 & 2.63E-06 & $4.76 \mathrm{E}-06$ & 5.03E-07 \\
\hline
\end{tabular}

\section{AO + UV Exposure}

\begin{tabular}{|c|c|c|c|c|c|c|c|c|c|}
\hline ID & Compound & AO Fluence & $\begin{array}{c}\text { Average } \\
\text { UV } \\
\text { Exposure }\end{array}$ & $\begin{array}{c}\text { Leakage } \\
\text { Rate }\end{array}$ & $\begin{array}{l}\text { Upper } \\
\text { Error } \\
\text { Limit }\end{array}$ & $\begin{array}{l}\text { Lower } \\
\text { Error } \\
\text { Limit }\end{array}$ & $\begin{array}{c}\text { Leakage } \\
\text { Rate }\end{array}$ & $\begin{array}{l}\text { Upper } \\
\text { Error } \\
\text { Limit }\end{array}$ & $\begin{array}{l}\text { Lower } \\
\text { Error } \\
\text { Limit }\end{array}$ \\
\hline & & [atoms $/ \mathrm{cm}^{2}$ ] & [ESH] & [lbm/day] & [lbm/day] & [lbm/day] & & & \\
\hline 63 & ELA-SA-401 & $6.03 E+21$ & 328.2 & 2.99E-05 & 3.47E-05 & 2.52E-05 & 1.36E-05 & 1.57E-05 & 1.14E-05 \\
\hline 63 & ELA-SA-401 & $6.03 E+21$ & 328.2 & $3.01 \mathrm{E}-05$ & $3.48 \mathrm{E}-05$ & 2.53E-05 & 1.36E-05 & $1.58 \mathrm{E}-05$ & 1.15E-05 \\
\hline 63 & ELA-SA-401 & $6.03 E+21$ & 558.3 & 4.52E-05 & 4.99E-05 & 4.05E-05 & 2.05E-05 & 2.26E-05 & 1.84E-05 \\
\hline 63 & ELA-SA-401 & $6.03 E+21$ & 558.3 & 4.40E-05 & 4.87E-05 & 3.92E-05 & 2.00E-05 & 2.21E-05 & 1.78E-05 \\
\hline 63 & ELA-SA-401 & $6.03 E+21$ & 827.2 & 8.07E-05 & 8.54E-05 & 7.61E-05 & 3.66E-05 & 3.87E-05 & 3.45E-05 \\
\hline 63 & ELA-SA-401 & $6.03 E+21$ & 827.2 & 7.65E-05 & $8.12 \mathrm{E}-05$ & 7.18E-05 & 3.47E-05 & 3.68E-05 & 3.26E-05 \\
\hline 63 & ELA-SA-401 & $6.03 E+21$ & 1162.6 & 1.25E-04 & 1.30E-04 & 1.20E-04 & & 5.90E-05 & 5.44E-05 \\
\hline 63 & ELA-SA-401 & $6.03 E+21$ & 1162.6 & 1.23E-04 & $1.28 \mathrm{E}-04$ & 1.17E-04 & 5.56E-05 & 5.81E-05 & 5.31E-05 \\
\hline 63 & ELA-SA-401 & $E+21$ & 1529.4 & & $2.21 \mathrm{E}-04$ & 2.03E-04 & & $1.00 \mathrm{E}-04$ & $9.21 \mathrm{E}-05$ \\
\hline 63 & ELA-SA-401 & $6.03 E+21$ & 1529.4 & $1.80 \mathrm{E}-04$ & $1.88 \mathrm{E}-04$ & $1.72 \mathrm{E}-04$ & 8.16E-05 & 8.53E-05 & 7.80E-05 \\
\hline 75 & ELA-SA-401 & $5.37 E+21$ & 324.3 & 2.73E-05 & $3.21 \mathrm{E}-05$ & $2.26 \mathrm{E}-05$ & $1.24 \mathrm{E}-05$ & 1.46E-05 & 1.03E-05 \\
\hline 175 & ELA-SA-401 & $5.37 E+21$ & 324.3 & 2.07E-05 & 2.54E-05 & 1.60E-05 & 9.38E-06 & 1.15E-05 & 7.26E-06 \\
\hline 175 & ELA-SA-401 & $5.37 \mathrm{E}+21$ & 554.8 & 5.68E-05 & $6.14 \mathrm{E}-05$ & 5.22E-05 & 2.58E-05 & 2.79E-05 & 2.37E-05 \\
\hline 175 & ELA-SA-401 & $5.37 \mathrm{E}+21$ & 554.8 & $4.50 \mathrm{E}-05$ & 4.97E-05 & 4.02E-05 & 2.04E-05 & $2.25 \mathrm{E}-05$ & 1.82E-05 \\
\hline 175 & ELA-SA-401 & $5.37 \mathrm{E}+21$ & 834.6 & 7.96E-05 & 8.43E-05 & 7.49E-05 & 3.61E-05 & 3.82E-05 & 3.40E-05 \\
\hline 175 & ELA-SA-401 & $5.37 E+21$ & 834.6 & 7.51E-05 & 7.97E-05 & 7.04E-05 & 3.40E-05 & 3.62E-05 & 3.19E-05 \\
\hline 175 & ELA-SA-401 & $5.37 \mathrm{E}+21$ & 834.6 & 7.19E-05 & 7.66E-05 & $6.72 \mathrm{E}-05$ & 3.26E-05 & 3.47E-05 & 3.05E-05 \\
\hline 175 & ELA-SA-401 & $5.37 E+21$ & 1158.2 & 1.46E-04 & $1.52 \mathrm{E}-04$ & 1.39E-04 & 6.60E-05 & 6.89E-05 & 6.30E-05 \\
\hline 175 & ELA-SA-401 & $5.37 E+21$ & 1158.2 & $1.41 \mathrm{E}-04$ & 1.47E-04 & 1.35E-04 & 6.41E-05 & 6.67E-05 & $6.12 \mathrm{E}-05$ \\
\hline 175 & ELA-SA-401 & $5.37 E+21$ & 1495.5 & 2.37E-04 & $2.48 \mathrm{E}-04$ & $2.27 \mathrm{E}-04$ & $1.08 \mathrm{E}-04$ & 1.12E-04 & 1.03E-04 \\
\hline 175 & ELA-SA-401 & 5.37E+21 & 1495.5 & 2.38E-04 & 2.52E-04 & 2.23E-04 & $1.08 \mathrm{E}-04$ & 1.14E-04 & $1.01 \mathrm{E}-04$ \\
\hline
\end{tabular}


4. VUV and NUV Components of Average UV Values

Parker Hannifin S0383-70

\begin{tabular}{|c|c|c|c|c|c|c|c|c|c|c|}
\hline \multirow[b]{2}{*}{ ID } & \multicolumn{2}{|c|}{ Exposure 1} & \multicolumn{2}{|c|}{ Exposure 2} & \multicolumn{2}{|c|}{ Exposure 3} & \multicolumn{2}{|c|}{ Exposure 4} & \multicolumn{2}{|c|}{ Exposure 5} \\
\hline & $\begin{array}{c}\text { VUV } \\
\text { [ESH] }\end{array}$ & $\begin{array}{c}\text { NUV } \\
{[\mathrm{ESH}]}\end{array}$ & $\begin{array}{l}\text { VUV } \\
\text { [ESH] }\end{array}$ & $\begin{array}{c}\text { NUV } \\
{[\mathrm{ESH}]}\end{array}$ & $\begin{array}{c}\text { VUV } \\
\text { [ESH] }\end{array}$ & $\begin{array}{l}\text { NUV } \\
\text { [ESH] }\end{array}$ & $\begin{array}{l}\text { VUV } \\
\text { [ESH] }\end{array}$ & $\begin{array}{c}\text { NUV } \\
{[E S H]}\end{array}$ & $\begin{array}{l}\text { VUV } \\
\text { [ESH] }\end{array}$ & $\begin{array}{c}\text { NUV } \\
\text { [ESH] }\end{array}$ \\
\hline 164 & 267 & 381.5 & 147.3 & 312.9 & 223.9 & 313.9 & 474.6 & 241.6 & 455 & 278.6 \\
\hline 165 & 250.4 & 395.3 & 147.3 & 312.9 & 240.86 & 302.8 & 474.6 & 241.6 & 427.8 & 289.6 \\
\hline
\end{tabular}

Parker Hannifin S0899-50

\begin{tabular}{|c|c|c|c|c|c|c|c|c|c|c|}
\hline \multirow[b]{2}{*}{ ID } & \multicolumn{2}{|c|}{ Exposure 1} & \multicolumn{2}{|c|}{ Exposure 2} & \multicolumn{2}{|c|}{ Exposure 3} & \multicolumn{2}{|c|}{ Exposure 4} & \multicolumn{2}{|c|}{ Exposure 5} \\
\hline & $\begin{array}{c}\text { VUV } \\
\text { [ESH] }\end{array}$ & $\begin{array}{c}\text { NUV } \\
\text { [ESH] }\end{array}$ & $\begin{array}{l}\text { VUV } \\
\text { [ESH] }\end{array}$ & $\begin{array}{c}\text { NUV } \\
\text { [ESH] }\end{array}$ & $\begin{array}{l}\text { VUV } \\
\text { [ESH] }\end{array}$ & $\begin{array}{c}\text { NUV } \\
\text { [ESH] }\end{array}$ & $\begin{array}{l}\text { VUV } \\
\text { [ESH] }\end{array}$ & $\begin{array}{c}\text { NUV } \\
\text { [ESH] }\end{array}$ & $\begin{array}{l}\text { VUV } \\
\text { [ESH] }\end{array}$ & $\begin{array}{c}\text { NUV } \\
\text { [ESH] }\end{array}$ \\
\hline 60 & 311.6 & 344.7 & 188.36 & 272.8 & 240.86 & 302.8 & 370.8 & 276.5 & 382.7 & 308 \\
\hline 169 & 250.4 & 395.3 & 158.3 & 301.9 & 286.1 & 273.36 & 451.8 & 250.4 & 382.7 & 308 \\
\hline
\end{tabular}

Esterline ELA-SA-401

\begin{tabular}{|c|c|c|c|c|c|c|c|c|c|c|}
\hline \multirow[b]{2}{*}{ ID } & \multicolumn{2}{|c|}{ Exposure 1} & \multicolumn{2}{|c|}{ Exposure 2} & \multicolumn{2}{|c|}{ Exposure 3} & \multicolumn{2}{|c|}{ Exposure 4} & \multicolumn{2}{|c|}{ Exposure 5} \\
\hline & $\begin{array}{l}\text { VUV } \\
\text { [ESH] }\end{array}$ & $\begin{array}{c}\text { NUV } \\
\text { [ESH] }\end{array}$ & $\begin{array}{l}\text { VUV } \\
\text { [ESH] }\end{array}$ & $\begin{array}{c}\text { NUV } \\
\text { [ESH] }\end{array}$ & $\begin{array}{l}\text { VUV } \\
\text { [ESH] }\end{array}$ & $\begin{array}{c}\text { NUV } \\
{[\text { ESH] }}\end{array}$ & $\begin{array}{l}\text { VUV } \\
\text { [ESH] }\end{array}$ & $\begin{array}{c}\text { NUV } \\
{[E S H]}\end{array}$ & $\begin{array}{l}\text { VUV } \\
\text { [ESH] }\end{array}$ & $\begin{array}{l}\text { NUV } \\
\text { [ESH] }\end{array}$ \\
\hline 63 & 311.6 & 344.7 & 158.3 & 301.9 & 223.9 & 313.9 & 404.6 & 266.2 & 455 & 278.6 \\
\hline 175 & 267 & 381.5 & 188.36 & 272.8 & 286.1 & 273.36 & 370.8 & 276.5 & 355.6 & 319 \\
\hline
\end{tabular}




\section{Appendix E Hypothesis Testing of Leakage Test Data}

\section{Theory}

The method of hypothesis testing used to analyze the leakage test data was similar to that used in a previous section (Appendix B), but is repeated here for completeness. Each of the leakage specimens tested were exposed to unique levels of (1) AO and (2) AO and UV. A statistical approach was used to confirm the validity of comparisons of average leakage rate values across the three materials for each condition. Statistical hypothesis analyses were performed to determine whether the individual data sets of the three materials were exposed to equivalent levels of $\mathrm{AO}$ and $\mathrm{AO} \& \mathrm{UV}$.

The authors assumed that the distribution about the population mean was normally distributed such that the confidence interval could be stated according to equation (D1):

$$
\bar{X} \pm t_{\alpha / 2} S / \sqrt{n}
$$

where:
$\bar{X} \quad$ the population mean
$t \quad$ the student $t$-value at a specified value of $\alpha$ for t-distribution with $(n-1)$ degrees of freedom
$\alpha \quad$ the significance level
$S \quad$ the standard deviation of the sample measurements
$n \quad$ the sample size

The authors further assumed that the mean of the sample, $\mu_{0}$, was contained within the confidence interval. The authors tested this assumption using the hypothesis testing techniques. ${ }^{29}$ If the resulting confidence interval, $t_{\alpha / 2} S / \sqrt{n}$, did not contain $\mu_{0}$, then the hypothesis was rejected. If $\mu_{0}$ was within the confidence interval, then the hypothesis could not be rejected. Therefore, the hypothesized value $\mu_{0}$ would be rejected if

$$
|T|=\left|\frac{\bar{X}-\mu_{0}}{S / \sqrt{n}}\right|>t_{\alpha / 2}
$$

\section{Application}

The above theory was used in the analysis of results of small scale leakage rate results of three candidate elastomers: Parker S0383-70, Parker S08998-50, and XELA-SA-401, denoted 70, 50, and 38, respectively. Each of the materials was tested in three different conditions: (1) as-received, (2) after AO exposure, and (3) subsequent to $\mathrm{AO}$ and UV exposures. In conditions (2) and (3) the exposure levels to AO and/or UV were varied for each sample, thereby motivating this hypothesis analysis.

The mean exposure levels of the three material data sets were compared to the sample population mean value using a significance level of $\alpha=0.05$. The performed calculations, along with explanation of terms are shown below.

\section{Condition (2): $A O$ Exposures}

The population mean $\bar{X}$ (the average of AO exposure levels for the there material data sets) was calculated to be $5.22 \times 10^{21}$ atoms $/ \mathrm{cm}^{2}$. Using equation (D2) with $\mu_{0}$ being the average level of AO exposure for each particular material, the analysis was performed as presented along with the corresponding value of $t$ for $\alpha=0.05$ (95\% confidence):

$\mathrm{AO}_{70}:\left|\frac{\bar{X}-\mu_{0}}{S / \sqrt{n}}\right|=\left|\frac{5.22 \times 10^{21}-5.41 \times 10^{21}}{1.13 \times 10^{21} / \sqrt{8}}\right|=0.463<t_{\alpha / 2}=2.365$ 
$\mathrm{AO}_{50}:\left|\frac{\bar{X}-\mu_{0}}{S / \sqrt{n}}\right|=\left|\frac{5.22 \times 10^{21}-5.15 \times 10^{21}}{1.45 \times 10^{21} / \sqrt{8}}\right|=0.135<t_{\alpha / 2}=2.365$
$\mathrm{AO}_{38}:\left|\frac{\bar{X}-\mu_{0}}{S / \sqrt{n}}\right|=\left|\frac{5.22 \times 10^{21}-5.11 \times 10^{21}}{1.73 \times 10^{21} / \sqrt{8}}\right|=0.187<t_{\alpha / 2}=2.365$

The above calculations confirm that the mean exposure values of $\mathrm{AO}$ were not statistically different for the three materials tested in condition (2). This confirms the validity of comparisons of average leakage rate values for these materials, as shown in Fig. 17.

\section{Condition (3): $A O$ and UV Exposures}

The AO population mean was calculated to be $\bar{X}=5.77 \times 10^{21}$ atoms $/ \mathrm{cm}^{2}$, while the UV population mean was $\bar{X}=1523.9$ ESH. Similarly as in condition (2) calculations, equation (D2) was used for analysis of average AO and average UV exposures.

$$
\begin{aligned}
& \mathrm{AO}_{70}:\left|\frac{\bar{X}-\mu_{0}}{S / \sqrt{n}}\right|=\left|\frac{5.77 \times 10^{21}-5.23 \times 10^{21}}{1.41 \times 10^{20} / \sqrt{4}}\right|=7.586>t_{\alpha / 2}=3.182 \\
& \mathrm{AO}_{50}:\left|\frac{\bar{X}-\mu_{0}}{S / \sqrt{n}}\right|=\left|\frac{5.77 \times 10^{21}-6.38 \times 10^{21}}{1.02 \times 10^{21} / \sqrt{4}}\right|=1.193<t_{\alpha / 2}=3.182 \\
& \mathrm{AO}_{38}:\left|\frac{\bar{X}-\mu_{0}}{S / \sqrt{n}}\right|=\left|\frac{5.77 \times 10^{21}-5.70 \times 10^{21}}{3.81 \times 10^{20} / \sqrt{4}}\right|=0.378<t_{\alpha / 2}=3.182 \\
& \mathrm{UV}_{70}:\left|\frac{\bar{X}-\mu_{0}}{S / \sqrt{n}}\right|=\left|\frac{1523.9-1544.9}{3.8 / \sqrt{4}}\right|=11.064>t_{\alpha / 2}=3.182 \\
& \mathrm{UV}_{50}:\left|\frac{\bar{X}-\mu_{0}}{S / \sqrt{n}}\right|=\left|\frac{1523.9-1514.3}{17.1 / \sqrt{4}}\right|=1.117<t_{\alpha / 2}=3.182 \\
& \mathrm{UV}_{38}:\left|\frac{\bar{X}-\mu_{0}}{S / \sqrt{n}}\right|=\left|\frac{1523.9-1512.4}{19.5 / \sqrt{4}}\right|=1.172<t_{\alpha / 2}=3.182
\end{aligned}
$$

The above calculation confirm that the mean AO and UV exposure levels of 50 and 38 compounds were not statistically different; however, the total amounts of AO exposure and UV exposure to which the 70 specimens were subjected were not statistically equivalent to the sample population mean. The average AO and UV exposures for the 70 samples were $13 \%$ lower and $2 \%$ higher, respectively, than the combined average of the 50 and 38 exposure levels. Nevertheless, the average leakage rate results of the 70 material were presented on the same plot (Fig. 17) along with 50 and 38 due to the similarity of exposure levels, while acknowledging the statistical deviation.

\section{Combined Conditions (2) and (3)}

In order to quantify the overall effect of space environment exposure (both AO and AO with UV) on the three candidate compounds, confirmation that the individual data sets of the materials in conditions (2) and (3) were exposed to statistically equivalent levels of $\mathrm{AO}$ was required. The mean $\mathrm{AO}$ exposure levels of the three material data sets in the two conditions were compared to the sample population mean value using a significance level of $\alpha=$ 0.05 . The AO population mean was calculated to be $\bar{X}=5.40 \times 10^{21}$ atoms $/ \mathrm{cm}^{2}$. Application of equation (D2) leads to the following calculations and results: 
$\mathrm{AO}_{70}$ condition (2): $\left|\frac{\bar{X}-\mu_{0}}{S / \sqrt{n}}\right|=\left|\frac{5.40 \times 10^{21}-5.41 \times 10^{21}}{1.13 \times 10^{21} / \sqrt{8}}\right|=0.004<t_{\alpha / 2}=2.365$

$\mathrm{AO}_{50}$ condition (2): $\left|\frac{\bar{X}-\mu_{0}}{S / \sqrt{n}}\right|=\left|\frac{5.40 \times 10^{21}-5.15 \times 10^{21}}{1.45 \times 10^{21} / \sqrt{8}}\right|=0.491<t_{\alpha / 2}=2.365$

$\mathrm{AO}_{38}$ condition (2): $\left|\frac{\bar{X}-\mu_{0}}{S / \sqrt{n}}\right|=\left|\frac{5.40 \times 10^{21}-5.11 \times 10^{21}}{1.73 \times 10^{21} / \sqrt{8}}\right|=0.485<t_{\alpha / 2}=2.365$

$\mathrm{AO}_{70}$ condition (3): $\left|\frac{\bar{X}-\mu_{0}}{S / \sqrt{n}}\right|=\left|\frac{5.40 \times 10^{21}-5.23 \times 10^{21}}{1.41 \times 10^{20} / \sqrt{4}}\right|=2.415<t_{\alpha / 2}=3.182$

$\mathrm{AO}_{50}$ condition (3): $\left|\frac{\bar{X}-\mu_{0}}{S / \sqrt{n}}\right|=\left|\frac{5.40 \times 10^{21}-6.38 \times 10^{21}}{1.02 \times 10^{21} / \sqrt{4}}\right|=1.910<t_{\alpha / 2}=3.182$

$\mathrm{AO}_{38}$ condition (3): $\left|\frac{\bar{X}-\mu_{0}}{S / \sqrt{n}}\right|=\left|\frac{5.40 \times 10^{21}-5.70 \times 10^{21}}{3.81 \times 10^{20} / \sqrt{4}}\right|=1.542<t_{\alpha / 2}=3.182$

Based on the above analysis, the mean levels of AO exposure among the specimens tested in conditions (2) and (3) were not statistically different, with a confidence level of $95 \%$. 


\begin{tabular}{|c|c|c|c|c|c|}
\hline \multicolumn{5}{|c|}{ REPORT DOCUMENTATION PAGE } & $\begin{array}{l}\text { Form Approved } \\
\text { OMB No. 0704-0188 }\end{array}$ \\
\hline \multicolumn{6}{|c|}{$\begin{array}{l}\text { The public reporting burden for this collection of information is estimated to average } 1 \text { hour per response, including the time for reviewing instructions, searching existing data sources, gathering and maintaining the } \\
\text { data needed, and completing and reviewing the collection of information. Send comments regarding this burden estimate or any other aspect of this collection of information, including suggestions for reducing this } \\
\text { burden, to Department of Defense, Washington Headquarters Services, Directorate for Information Operations and Reports } 070704-188), 1215 \text { Jefferson Davis Highway, Suite } 1204 \text {, Arlington, VA } 222022-4302 \text {. } \\
\text { Respondents should be aware that notwithstanding any other provision of law, no person shall be subject to any penalty for failing to comply with a collection of information if it does not display a currently valid OMB } \\
\text { control number. } \\
\text { PLEASE DO NOT RETURN YOUR FORM TO THE ABOVE ADDRESS. }\end{array}$} \\
\hline \multicolumn{2}{|c|}{$\begin{array}{l}\text { 1. REPORT DATE (DD-MM-YYYY) } \\
01-01-2008\end{array}$} & \multicolumn{3}{|c|}{$\begin{array}{l}\text { 2. REPORT TYPE } \\
\text { Technical Memorandum }\end{array}$} & 3. DATES COVERED (From - To) \\
\hline \multirow{3}{*}{\multicolumn{5}{|c|}{$\begin{array}{l}\text { 4. TITLE AND SUBTITLE } \\
\text { Characteristics of Elastomer Seals Exposed to Space Environments }\end{array}$}} & 5a. CONTRACT NUMBER \\
\hline & & & & & 5b. GRANT NUMBER \\
\hline & & & & & 5c. PROGRAM ELEMENT NUMBER \\
\hline \multirow{3}{*}{\multicolumn{5}{|c|}{$\begin{array}{l}\text { 6. AUTHOR(S) } \\
\text { Daniels, Christopher, C.; de Groh, Henry, C., III; Dunlap, Patrick, H., Jr.; Finkbeiner, Joshua, } \\
\text { R.; Steinetz, Bruce, M.; Bastrzyk, Marta, B.; Oswald, Jay, J.; Banks, Bruce, A.; Dever, Joyce, } \\
\text { A.; Miller, Sharon, K.; Waters, Deborah, L. }\end{array}$}} & 5d. PROJECT NUMBER \\
\hline & & & & & 5e. TASK NUMBER \\
\hline & & & & & $\begin{array}{l}\text { 5f. WORK UNIT NUMBER } \\
\text { WBS 644423.06.31.04.01.03.22 }\end{array}$ \\
\hline \multicolumn{5}{|c|}{$\begin{array}{l}\text { 7. PERFORMING ORGANIZATION NAME(S) AND ADDRESS(ES) } \\
\text { National Aeronautics and Space Administration } \\
\text { John H. Glenn Research Center at Lewis Field } \\
\text { Cleveland, Ohio 44135-3191 }\end{array}$} & $\begin{array}{l}\text { 8. PERFORMING ORGANIZATION } \\
\text { REPORT NUMBER } \\
\text { E-16189 }\end{array}$ \\
\hline \multirow{2}{*}{\multicolumn{5}{|c|}{$\begin{array}{l}\text { 9. SPONSORING/MONITORING AGENCY NAME(S) AND ADDRESS(ES) } \\
\text { National Aeronautics and Space Administration } \\
\text { Washington, DC 20546-0001 }\end{array}$}} & $\begin{array}{l}\text { 10. SPONSORING/MONITORS } \\
\text { ACRONYM(S) } \\
\text { NASA }\end{array}$ \\
\hline & & & & & $\begin{array}{l}\text { 11. SPONSORING/MONITORING } \\
\text { REPORT NUMBER } \\
\text { NASA/TM-2008-215005; AIAA-2007- } \\
5741\end{array}$ \\
\hline \multicolumn{6}{|c|}{$\begin{array}{l}\text { 12. DISTRIBUTION/AVAILABILITY STATEMENT } \\
\text { Unclassified-Unlimited } \\
\text { Subject Category: } 37 \\
\text { Available electronically at http://gltrs.grc.nasa.gov } \\
\text { This publication is available from the NASA Center for AeroSpace Information, 301-621-0390 }\end{array}$} \\
\hline \multicolumn{6}{|c|}{ 13. SUPPLEMENTARY NOTES } \\
\hline \multicolumn{6}{|c|}{$\begin{array}{l}\text { 14. ABSTRACT } \\
\text { A universal docking and berthing system is being developed by the National Aeronautics and Space Administration (NASA) to support all future space exploration missions to } \\
\text { low-Earth orbit (LEO), to the Moon, and to Mars. The Low Impact Docking System (LIDS) is being designed to operate using a seal-on-seal configuration in numerous space } \\
\text { environments, each having unique exposures to temperature, solar radiation, reactive elements, debris, and mission duration. As the LIDS seal is likely to be manufactured from } \\
\text { an elastomeric material, performance evaluation of elastomers after exposure to atomic oxygen (AO) and ultraviolet radiation (UV) was conducted, of which the work } \\
\text { presented herein was a part. Each of the three candidate silicone elastomer compounds investigated, including Esterline ELA-SA-401, and Parker Hannifin S0383-70 and } \\
\text { S0899-50, was characterized as a low outgassing compound, per ASTM E595, having percent total mass loss (TML) less than } 1.0 \text { percent and collected volatile condensable } \\
\text { materials (CVCM) less than } 0.1 \text { percent. Each compound was compatible with the LIDS operating environment of - } 50 \text { to } 500^{\circ} \mathrm{C} \text {. The seal characteristics presented include } \\
\text { compression set, elastomer-to-elastomer adhesion, and o-ring leakage rate. The ELA-SA-401 compound had the lowest variation in compression set with temperature. The } \\
\text { S0383-70 compound exhibited the lowest compression set after exposure to AO and UV. The adhesion for all of the compounds was significantly reduced after exposure to AO } \\
\text { and was further decreased after exposure to AO and UV. The leakage rates of o-ring specimens showed modest increases after exposure to AO. The leakage rates after } \\
\text { exposure to AO and UV were increased by factors of up to } 600 \text { when compared to specimens in the as-received condition. }\end{array}$} \\
\hline \multicolumn{6}{|c|}{$\begin{array}{l}\text { 15. SUBJECT TERMS } \\
\text { Seals; Elastomer; Environment; Temperature; Atomic oxygen; Ultraviolet; Radiation; Compound }\end{array}$} \\
\hline \multicolumn{3}{|c|}{ 16. SECURITY CLASSIFICATION OF: } & $\begin{array}{l}\text { 17. LIMITATION OF } \\
\text { ABSTRACT }\end{array}$ & $\begin{array}{l}\text { 18. NUMBER } \\
\text { OF }\end{array}$ & $\begin{array}{l}\text { 19a. NAME OF RESPONSIBLE PERSON } \\
\text { STI Help Desk (email:help@sti.nasa.gov) }\end{array}$ \\
\hline $\begin{array}{l}\text { a. REPORT } \\
\text { U }\end{array}$ & $\begin{array}{l}\text { b. ABSTRACT } \\
\text { U }\end{array}$ & $\begin{array}{l}\text { c. THIS } \\
\text { PAGE } \\
\text { U }\end{array}$ & UU & $\begin{array}{l}\text { PAGES } \\
41\end{array}$ & $\begin{array}{l}\text { 19b. TELEPHONE NUMBER (include area code) } \\
301-621-0390\end{array}$ \\
\hline
\end{tabular}



